\title{
Potential Medicinal Plants for the Treatment of Dengue Fever and Severe Acute Respiratory Syndrome-Coronavirus
}

\author{
Mohammed S. M. Saleh (D) and Yusof Kamisah *(D) \\ Department of Pharmacology, Faculty of Medicine, Universiti Kebangsaan Malaysia Medical Center, \\ Cheras 56000, Kuala Lumpur, Malaysia; medsaleh@ukm.edu.my \\ * Correspondence: kamisah_y@ppukm.ukm.edu.my; Tel.: +60-3-9145-9575; Fax: +60-3-9145-9547
}

check for updates

Citation: Saleh, M.S.M.; Kamisah, Y. Potential Medicinal Plants for the Treatment of Dengue Fever and Severe Acute Respiratory Syndrome-Coronavirus. Biomolecules 2021, 11, 42. https://doi.org/ 10.3390/biom 11010042

Received: 15 December 2020 Accepted: 27 December 2020 Published: 30 December 2020

Publisher's Note: MDPI stays neutral with regard to jurisdictional clai$\mathrm{ms}$ in published maps and institutional affiliations.

Copyright: (C) 2020 by the authors. Licensee MDPI, Basel, Switzerland. This article is an open access article distributed under the terms and conditions of the Creative Commons Attribution (CC BY) license (https:// creativecommons.org/licenses/by/ $4.0 /)$.

\begin{abstract}
While dengue virus (DENV) infection imposes a serious challenge to the survival of humans worldwide, severe acute respiratory syndrome-coronavirus (SARS-CoV) remains the most devastating pandemic in human history. A significant number of studies have shown that plantderived substances could serve as potential candidates for the development of safe and efficacious remedies for combating these diseases. Different scientific databases were used to source for literature on plants used against these infections. Thirty-five studies described the traditional use of 25 species from 20 families for treating DENV infection with Carica papaya and Euphorbia hirta were the most widely used across different regions. 13 in vivo studies, 32 in vitro studies, and eight clinical studies were conducted on 30 species from 25 families against different DENV serotypes, while plants from 13 families were reported to inhibit different forms of SARS-CoV, all of which were investigated through in vitro studies. Phytoconstituents belonging to various chemical classes were identified to show a wide range of antiviral activity against these infections. Extensive studies on the potentials of medicinal plants are needed to confirm their efficacy. This paper reveals the capabilities of medicinal plants and their phytochemicals in inhibiting DENV and SARS-CoV infections.
\end{abstract}

Keywords: dengue virus; medicinal plants; ethnobotany; pharmacology; phytochemical; SARS-CoV

\section{Introduction}

According to the World Health Organization (WHO), infectious diseases remain the sixth leading cause of deaths globally [1]. Emerging and reemerging infectious diseases have continued to be a persistent threat to human population. Among numerous infectious diseases, viral diseases caused by varieties of old and new viruses have imposed a serious challenge to the survival of mankind. Viral infections remain one of the main causes of death worldwide [2]. It is terrifying that the number of patients diagnosed with these infections keeps on increasing every year. Among the top perilous viral diseases are Ebola (over 11,000 deaths in 2019) [3], acquired immunodeficiency syndrome (AIDS) which accounted the deaths of 1.1 million people globally [4], influenza (300,000-500,000 deaths yearly) [5,6], dengue fever (over 390 million, of which 96 million manifest clinically) [7], and severe acute respiratory syndrome coronavirus 2 (SARS-CoV-2) (also known as COVID-19 in the 2019 outbreak) (over 60 million cases with approximately 1,416,292 deaths worldwide) [1].

With the emergence of new viral strains and increasing resistance to standard antiviral therapy, and the fact that most of the available antiviral therapies are non-specific for particular viruses [8], the key focus of medical research is therefore centered on the development of specific and cost-effective antiviral regimens [9,10], which include alternative treatment from herbal sources. At present, several antiviral vaccinations are available including human papilloma virus [11], hepatitis A and B virus [12], varicella, measles, mumps, rubella [13], and rabies [14]. However, there are still no vaccines for a few other viral infections.

Dengue fever is a viral infection that has imposed serious economic burdens in both tropical and sub-tropical regions [15]. More than 300 million cases are recorded annually 
with nearly 22,000 deaths [16]. Globally, dengue fever affects approximately 2.5 billion people with an estimated 50-100 million new cases annually [17]. The endemic disease occurs in more than 100 countries including Africa, Asia, America, Eastern Mediterranean and Western Pacific being the most affected regions [18] (Figure 1). Recently, the occurrence of dengue has rapidly increased, reaching the pandemic level [19]. More than 20 African countries were affected by an epidemic between 1960 and 2017. However, many outbreaks are never officially reported [20]. Dengue fever is caused by four distinct but antigenically related flavivirus serotypes with dengue virus (DENV) type-2 (DENV-2) reported to be more deadly than all other serotypes [21]. The disease is prevalent in urban and semi-urban areas and is transmitted by female Aedes aegypti mosquitoes [22]. The incubation period after the virus gets into the human body varies from 3-14 days, after which symptoms ranging from mild to severe begin to manifest. Early symptoms may include headache, fever, severe muscle, and joint pain [23]. Severe cases are characterized by hemorrhagic fever syndrome, which may result in dengue shock syndrome [24]. Its treatment includes standard management of general fever as well as other symptomatic treatments [25]. Dengvaxia, the first dengue vaccine, was licensed a few years back for clinical use [26]. The safety of the vaccine however, is still questionable due to findings that it could increase the risk of dengue fever severity in individuals with no prior history of DENV infection [27].

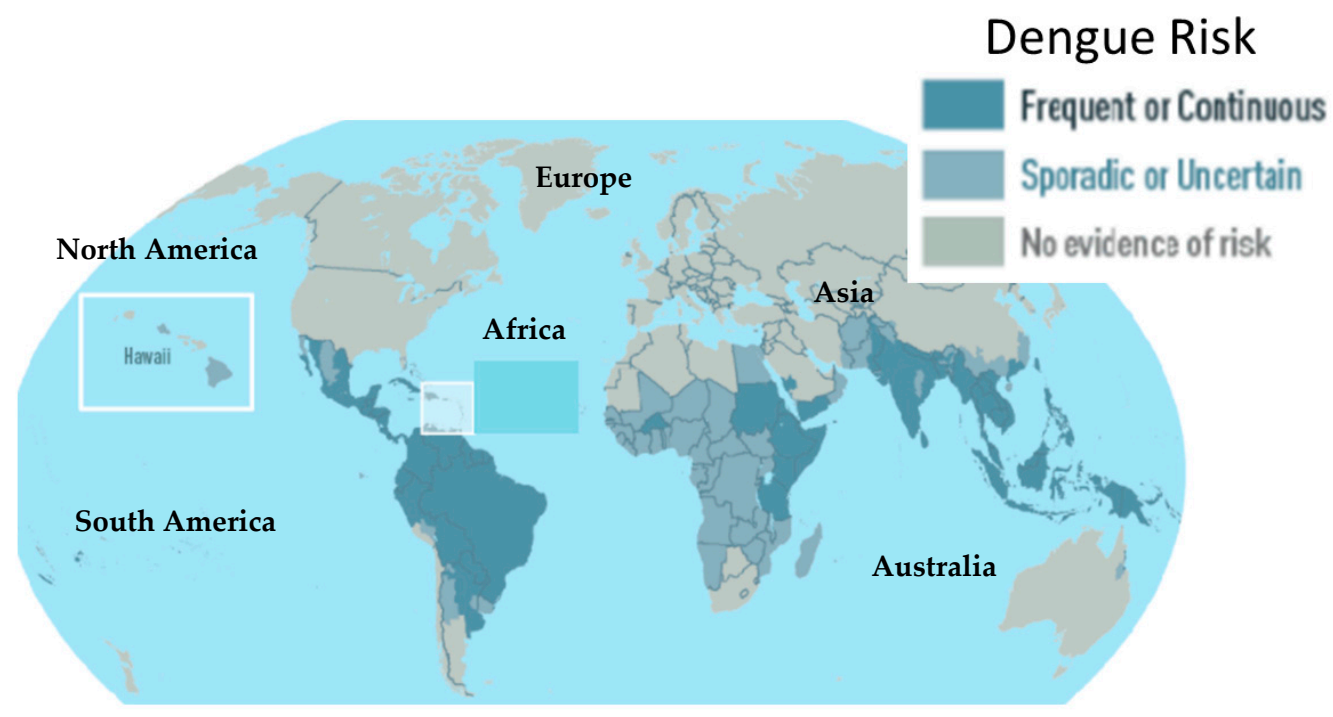

Figure 1. Global map showing the regions affected by dengue. Adapted from [28].

On the other hand, the novel COVID-19 is currently a global health crisis threatening the whole world. It has swiftly spread across various countries from its discovery in Wuhan City, Hubei Province of China [29]. As of 9 December 2020, over 60 million cases of COVID-19 and 1,416,292 deaths have been reported [1]. There have been two incidents of transmission from animal $\beta$-coronaviruses to humans in the last two decades which had resulted in serious diseases [30]: severe acute respiratory syndrome coronavirus (SARS$\mathrm{CoV}$ ), which was passed from bats onto humans through palm civet cats (intermediary host) in China in 2002-2003 [31], and Middle East respiratory syndrome coronavirus (MERS$\mathrm{CoV}$ ), transmitted from bats to humans via dromedary camels in 2012 in Saudi Arabia [32]. The latest coronavirus outbreak, recognized as SARS-CoV-2 or COVID-19, occurred in December 2019. It has more than $95 \%$ homology and more than $70 \%$ similarity with the bat coronavirus SARS-CoV-2 HKG/HKU strain and SARS-CoV, respectively [30]. Since then, the number of cases keeps increasing rapidly with the majority of human-to-human transmission [33]. As of 9 December 2020, the United States has the highest number with almost 15 million cases and more than 281,000 deaths, followed by India (almost 10 million cases and 141,360 deaths) and Brazil (six million cases and almost 178,009 deaths) [34]. Prevention of this disease is very crucial since there is no approved treatment for the 
infection. However, few vaccines have been developed for COVID-19 [11] with the hope that the pandemic could be lessened and finally eradicated.

Although DENV and SARS-CoV belong to different viral families and their characteristics such as structure, entry mechanism, replication, and pathogenicity are different, they manifest similar early signs and symptoms of fever, headache, joint pain, low platelet and white cell counts [35], which could lead to misdiagnosis. Both DENV and SARS-CoV are endemic to several parts of the world, while COVID-19 has become a pandemic. More importantly, some medicinal plants and their bioactive compounds have been reported to be effective for the inhibition of both infections, either by reducing viral load or by preventing viral replication. Houttuynia cordata and Boesenbergia rotunda are such examples. The extracts of both plants have been reported to inhibit both DENV-2 [36,37] and SARS CoV-2 [38-40]. Furthermore, compounds such panduratin and quercetin from these plants and other plants also inhibit both viral infections.

A greater percentage of people in tropical and sub-tropical regions rely on herbal medicine to cure various diseases and infections. Therefore, natural products could be one of the major sources for the development of antiviral drugs. About $80 \%$ of the population in developing countries, especially in Asia and Africa, use natural products from plants for their primary healthcare [41]. Plant extracts from different plant parts (stem, root, leaves, seeds, fruits, and flowers) [42], phytoconstituents (isolated compounds), nutraceuticals, and dietary supplements have been extensively used in treating a wide range of infectious and non-infectious diseases. They have also become the main sources of tested material in the development of several drugs including antiviral drugs based on ethnomedicinal practices [43]. According to the WHO, $25 \%$ of the commonly used drugs contain compounds that are purified from plants [44]. Due to many harmful side effects of synthetic drugs and increased microorganism resistance to standard antimicrobial therapy, alternative treatments from traditional herbal medicines have been widely explored [45]. Several medicinal plants have been reported to possess significant antiviral properties at different stages of viral growth $[46,47]$ and many have been used for treating viral infections, both in humans and animals including DENV infection [48-50]. Moreover, many phytoconstituents have been suggested to be potential inhibitors of SARS-CoV through in silico studies [51] and molecular docking/modeling [52-54]. The aim of this article is therefore to provide a concise review on the potential medicinal plants for the treatment of DENV infection and SARS-CoV by providing more insights on the role of natural remedies such as medicinal plants and pure bioactive metabolites on the development and advancement of anti-DENV and anti-SARS-CoV drugs.

\section{Evidence Acquisition}

A systematic literature search using Google Scholar, Scielo, Scopus, Web of Science, and PubMed was conducted to determine various medicinal plants traditionally used for treating DENV and SARS-CoV infections from May to September 2020. Sets of keywords were used for the search. The keywords for DENV were "traditional plants" AND "dengue", "active plant extracts" AND "dengue and bioactive compounds" AND "dengue"; while for SARS-CoV they were "medicinal plants" AND "SARS-CoV" and "bioactive compounds" AND "SARS-CoV". A total of 96 full text articles were retrieved on DENV, and 42 on SARS-CoV infections were included in this review.

\section{Traditional Plants Used for Dengue Treatment}

Many plants from the Lamiaceae family are used for the treatment of DENV infection by various tribes across different regions. However, the most commonly used plants are Carica papaya (Caricaceae) (papaya) and Euphorbia hirta (Euphorbiaceae), as shown in Table 1. Different parts of these plants such as leaves, roots, stems, and flowers are used in different formulations-decoction, infusion and leaf juice-to treat the ailment. In the Philippines, papaya leaves are pounded and squeezed to extract the juice, which is then orally administered to affected patients to improve low platelet count $[55,56]$. In Fiji, a 
decoction of the female papaya leaves is used [57]. Mixture of the fruits and leaves are used by the people of Tamil Nadu in South India to improve the symptoms of dengue fever [58], while Lawachara Forest Reserve dwellers in Bangladesh use an oral decoction of unripe fruits for the same purpose [59]. Meanwhile, the use of different parts of Euphorbia hirta is reported to cure dengue fever. Some use a water decoction of the leaves and stems $[56,60,61]$, while topical uses of stem barks, barks and roots are also reported to reduce dengue fever-related symptoms like fever, headache, skin blister, nose and mouth bleeding [61]. Laguna villagers in the Philippines use a decoction of the roots, stem, and leaves of the plant [55]. Other notable plants that are traditionally utilized for DENV treatment include leaf juice of Mikania cordata (Asteraceae) used by the Santal tribe in the Thakurgaon District of Bangladesh to bring down the fever [62], and a decoction of barks and bulbs of Annana reticulata and the leaves of Mentha arvensis (Lamiaceae), Synsepalum dulcificum (Sapotaceae) and Vitex negundo (Lamiaceae) used by the Matigsalug tribe in Davao City, the Philippines [60]. Additionally, decoction of Protium spruceanum (Burceraceae) stem bark with lemon was also reported by the Porvenir community in India to effectively cure dengue fever [63], whereas its Chhattisgarh tribes use the leaf extract of Azardirachta indica (Meliaceae) [64]. Decoction of a mixture of the rhizome and leaves of Zingiber purpureum (Zingiberaceae) with a clove of onion and turmeric are used by the Atingola people of Indonesia for similar treatment [65].

Table 1. Ethnomedicinal plants for the treatment of dengue fever.

\begin{tabular}{|c|c|c|c|c|}
\hline Name & Family & Part Used & Preparation & Reference \\
\hline Annona reticulata & Annonaceae & Barks and bulbs & Decoction & {$[60]$} \\
\hline Andrapogon citratum & Poaceae & Oil & Oil put on candles & [66] \\
\hline Azadirachta indica & Meliaceae & Leaves & Extracts & [64] \\
\hline Brassica campestris & Brassicaceae & Oil & Mixture with camphor & [67] \\
\hline \multirow[t]{5}{*}{ Carica papaya } & Caricaceae & Leaves & Juice & [56] \\
\hline & & Fruits & Oral decoction of unripe fruit & [59] \\
\hline & & Leaves and fruits & Not mentioned & [58] \\
\hline & & Female leaves & Decoction, (boiling the leaf juice) & [57] \\
\hline & & Leaves & Pounding and extraction & [55] \\
\hline Catharanthus roseus & Apocynaceae & Whole plant & Oral decoction & [68] \\
\hline Citrus limon & Rutaceae & Pulps & Juice mixed with Protium spruceanum & [63] \\
\hline Clerodendrum viscosum & Lamiaceae & Leaves & Not mentioned & [66] \\
\hline Coleus scutellarioides & Lamiaceae & Leaves & Juice & [60] \\
\hline Enicostemma hyssopifolium & Gentianaceae & Not stated & Decoction & [69] \\
\hline Euodia species & Rutaceae & Leaves & Water extract & {$[65]$} \\
\hline \multirow[t]{5}{*}{ Euphorbia hirta } & Euphorbiaceae & Leaves & Decoction & {$[56,60]$} \\
\hline & & Leaves and stems & Decoction & [70] \\
\hline & & Roots & Oral decoction & [71] \\
\hline & & Leaves & Decoction and infusion & [61] \\
\hline & & Leaves, stems and roots & Decoction & [55] \\
\hline Mentha arvensis & Lamiaceae & Leaves & Decoction & {$[60]$} \\
\hline Mikania micrantha & Asteraceae & Leaves & Cold maceration & [72] \\
\hline Mikania cordata & Asteraceae & Leaves & Leaves juice & [62] \\
\hline Musa paradisica & Musaceae & Latex of the stems & Decoction & \\
\hline \multirow[t]{2}{*}{ Ocinum sanctum } & Lamiaceae & Leaves & Juice & [57] \\
\hline & & Leaves & Juice & [67] \\
\hline Physalis angulata & Solanaceae & Leaves & Oral infusion & [72] \\
\hline Phytolacca bogotensis & Phytolaccaceae & Fresh leaves & Infusion of fresh leaves & [73] \\
\hline Protium spruceanum & Burseraceae & Stem barks & Decoction with Citrus limon & {$[63]$} \\
\hline \multirow[t]{2}{*}{ Psidium guajava } & Myrtaceae & Leaves & Decoction & [74] \\
\hline & & Leaves and young fruits & Not mentioned & [75] \\
\hline Tinospora cordifolia & Menispermaceae & Leaves and stems & Decoction & [74] \\
\hline Trigonella foenam & Fabaceae & Leaves & Water infusion & [74] \\
\hline Synespalum dulcificum & Sapotaceae & Leaves & Juice & [60] \\
\hline Vitex negundo & Lamiaceae & Leaves & Decoction & [60] \\
\hline Zingiber purpureum & Zingiberaceae & Rhizomes and leaves & Oral decoction mixed with turmeric and onion & [65] \\
\hline
\end{tabular}




\section{Pharmacologically Active Medicinal Plants and Isolated Compounds against Dengue Virus}

After comprehensive search on databases, 13 in vivo studies, 32 in vitro studies, and eight clinical studies were identified to have been conducted on 30 plant species from 25 families against DENV infection. As previously mentioned, Carica papaya and Euphorbia hirta are the most popular species in traditional herbal medicines for treating DENV infection. The most reported plant part investigated is the leaves.

\subsection{In Vivo Studies}

One of the significant clinical features of dengue fever is a reduction in platelet count. Many plant species have the ability to boost platelet count. Leaf extract of C. papaya has been demonstrated to augment platelet count in various dengue fever models in animals [76-78], in addition to reducing clotting time in thrombocytopenic rats [76]. Other plant species that show similar activity are Ipomea batata and Aternanthera sessillis [77], Eurycoma longifolia [69], and E. hirta [15,77,78]. However, M. charantia did not show similar effects in the DENV-infected Sprague-Dawley rats [77]. Aqueous extract of Eurycoma longifolia root also showed 30\% reduction in viral load in AG129 DENV-infected mice [79]. Another study demonstrated that oral administration of Curcuma longa remarkably reduced viral loads in ddY mice after $24 \mathrm{~h}$ [80]. Aqueous extract of Azadirachta indica leaves at 20-30 mg/mL (maximum non-toxic concentration) completely inhibited viral replication as confirmed by the absence of virus specific $511 \mathrm{bp}$ amplicon in real-time polymerase chain reaction (RT-PCR) and the absence of DENV-related symptoms in DENV-infected suckling mice [81]. Freeze-dried C. papaya leaves also increased plasma monocyte chemoattractant protein-1 (MCP-1) levels during the peak of viremia when given orally to AG129 dengueinfected mice, suggesting the possible immunomodulatory capacity of this plant during DENV infection [82].

It seems that $C$. papaya is the most studied plant in the dengue fever model. However, more research studies need to be conducted to better understand the beneficial effects of the plant extracts and the active phytoconstituents on DENV infection biology. The effects of medicinal plants on the pathophysiology of dengue concerning the mechanisms that govern the causes of capillary leakage and decrease in platelet count could also be studied in animal models. Many mouse models such as knockout mice or transgenic mice can also be employed to evaluate anti-DENV activity of the medicinal plans [83]. Therefore, any involvement or modulation of certain genes by the extract could be investigated.

\subsection{In Vitro Studies}

Virtually all in vitro studies were centered on the inhibitory effects of various medicinal plants against DENV replications. Infection by cytocidal viruses is usually associated with changes in cell morphology and physiology as well as sequential cellular biosynthetic events. Reduction in cytopathic effect-structural changes in host cell due to viral invasionis the major technique used for the detection of the extract's inhibitory capacity against DENV. Polar extracts such as aqueous [36,81,84], methanol [50,84-86], and ethanol [87,88] have been reported to possess anti-dengue activity. The inhibitory potential is attributable to the presence of polyphenols and terpenes [88]. The extract showed good inhibitory effects that ranged from $0.8 \mu \mathrm{g} / \mathrm{mL}$ to $1900 \mu \mathrm{g} / \mathrm{mL}$ with percentage inhibition more than $34 \%$ up to total inhibition. Methanol extracts of Cymbopogan citratus, Andrographis paniculata, Momordica charantia, Ocimum sanctum, Pelargonium citrosum, and Citrus limon showed inhibitory effects on DENV type-1 (DENV-1) growth in Vero E6 cells with A. paniculata exhibiting the highest activity followed by $M$. charantia [50]. Similar findings were also reported in ethanol and aqueous extracts of $A$. paniculata leaves $[84,85]$. The ethanol extract possessed higher inhibitory potential (75\%), attributable to the presence of polyphenols and terpenes [88]. Meanwhile, another study confirmed the strong inhibitory effect of a Cymbopogon citratus methanol extract of about $98.8 \%$ against DENV-2 New Guinea C strain (NGC) at a dose of $20 \mu \mathrm{g} / \mathrm{mL}$ [86]. Other extracts that showed similar inhibition 
include Acorus calamus and Myristica factual (96.5\% and 122.7\%, respectively). Aqueous extract of Azadirachta indica leaves had totally inhibited $100-10,00050 \%$ tissue culture infective dose (TCID 50 ) of DENV-2 at its maximum non-toxic concentration $(1.897 \mathrm{mg} / \mathrm{mL})$, marked by the lack of cytopathic effects [81]. In a similar context, leaf methanol extracts of Spondias mombin and Spondias tuberosa showed promising inhibitory capacity against DENV-2 replication at concentrations of 3.31 and $17.98 \mu \mathrm{g} / \mathrm{mL}$, respectively, believed to be due to the presence of rutin, quercetin, and ellagic acid in both plants [85]. Petroleum ether extract of Alternanthera philoxeroides was also reported to strongly inhibit DENV with a median effective concentration $\left(\mathrm{EC}_{50}\right)$ value of $47.43 \mu \mathrm{g} / \mathrm{mL}$ [89]. Other plants that were reported with the activity include Rhizophora apiculate, Flagellaria indica, and Cladogynos orientalis, Houttuynia cordata [87], E. hirta [90], Cissampelos pareira [82], Curcuma longa [72], and Psidium quajava [83].

Almost all parts of the above-mentioned plants like aerial parts [82], roots [83], and stem barks $[83,84]$ as well as the whole plants [85] show protective effects against DENV, which are not restricted to DENV-2 or DENV-1 only, but also against type 3 (DENV-3) and type 4 (DENV-4) [82,83]. Various medicinal plants investigated in vitro, in vivo, and clinical studies against DENV infection are shown in Table 2. Generally, many medicinal plants extracted mostly with polar solvents such as water, methanol, and ethanol exhibit significant antiviral activity. We could therefore infer that these solvents are capable of extracting the antiviral compounds from any medicinal plants. Mechanistic antiviral studies of the plant extracts are still lacking. More studies need to be conducted to explore this aspect to combat DENV infection.

\subsection{Clinical Studies}

Among many medicinal plants with anti-DENV potentials, Carica papaya has been tested clinically in many studies. Administration of $25 \mathrm{~mL}$ of plant aqueous leaf extract was found to reduce the severity of dengue fever in patients by increasing platelet, white blood cell as well as neutrophil counts in the blood [91]. Similarly, in a clinical study conducted on 12 patients with dengue fever with a platelet count less than $130,000 / \mathrm{mm}^{3}$, two doses $(5 \mathrm{~mL})$ of $C$. papaya leaf extract administered at $8 \mathrm{~h}$ intervals along with standard dengue symptomatic care, resulted in an increase in platelet count and white blood cell count within $24 \mathrm{~h}$ of treatment [92]. Oral administration of Carica papaya leaf juice at a dose of $30 \mathrm{~mL}$ for three consecutive days also elevated mean platelet count in 228 patients with dengue fever and dengue hemorrhagic fever compared to the control group [93]. It therefore could prevent the complications of thrombocytopenia [94], and shorten the length of hospital stay in these patients [95]. Similar outcomes were also reported by a recent study [96] that also showed C. papaya treatment reduced plasma tumor necrosis factor- $\alpha$, interferon- $\gamma$, and interleukin- 6 as well as mean dengue non-structural protein 1 (NS1). The findings confirmed the immunomodulatory property of the plant seen in the animal study. A clinical study on E. hirta aqueous extract demonstrated that oral administration of the extract to patients with dengue fever raised platelet and total leukocyte counts, but had no significant effect on hematocrit [97]. Not many clinical studies on the anti-DENV activity in medicinal plants have been carried out. More such studies are needed to confirm the effectiveness of the extracts and/or their isolated bioactive compounds on DENV. 
Table 2. Pharmacologically active medicinal plants for the treatment of dengue viral infection.

\begin{tabular}{|c|c|c|c|c|c|}
\hline Plant & Family & Part Used & $\begin{array}{l}\text { Type of } \\
\text { Study }\end{array}$ & Mode of Action & Reference \\
\hline $\begin{array}{l}\text { Alternanthera } \\
\text { photoperiods }\end{array}$ & Amaranthaceae & Whole plant & In vitro & Inhibited DENV-2 replication $\left(\mathrm{IC}_{50}=47.43 \mu \mathrm{g} / \mathrm{mL}\right)$ & [89] \\
\hline \multirow{4}{*}{$\begin{array}{c}\text { Alternanthera sessillis } \\
\text { Acorus calamus } \\
\text { Andrographis } \\
\text { paniculata } \\
\text { Ocimum sanctum } \\
\text { Arrabidaea pulchra }\end{array}$} & Amaranthaceae & Leaves & In vivo & Significant platelet increasing activity & [77] \\
\hline & Acoracea & Leaves & In vitro & Inhibited DENV-2 replication ( $96.5 \%$ at a dose of $20 \mu \mathrm{g} / \mathrm{mL})$ & [86] \\
\hline & Flaviviridae & Leaves & In vitro & Anti-DENV-1 activity in HEPG2 (78.3 $\pm 2.9 \mathrm{PFU} / \mathrm{mL})$ & {$[88]$} \\
\hline & $\begin{array}{l}\text { Lamiaceae } \\
\text { Bignoniaceae }\end{array}$ & $\begin{array}{l}\text { Leaves } \\
\text { Leaves }\end{array}$ & $\begin{array}{l}\text { In vitro } \\
\text { In vitro }\end{array}$ & $\begin{array}{l}\text { Anti-DENV-1 activity in HEPG2 }(1020.0 \pm 271.0 \mathrm{PFU} / \mathrm{mL}) \\
\text { Inhibited DENV-2 }\left(\mathrm{EC}_{50}=46.8 \pm 1.6 \mu \mathrm{g} \mathrm{mL}^{-1}\right)\end{array}$ & $\begin{array}{l}{[98]} \\
{[84]}\end{array}$ \\
\hline \multirow[t]{3}{*}{ Azadirachta indica } & Meliaceae. & Leaf extract & $\begin{array}{l}\text { In vitro and } \\
\text { in vivo }\end{array}$ & Inhibited DENV-2 replication in both in vitro and in vivo & {$[81]$} \\
\hline & & Leaves & In vivo & Increased the platelet counts & [99] \\
\hline & & Leaf extract & Human & $\begin{array}{l}\text { Increased the platelet counts and the total white cell counts had } \\
\text { increased }\end{array}$ & {$[92]$} \\
\hline \multirow{9}{*}{ Carica papaya } & Caricaceae & Leaf extract & Human & Increased the platelet counts & [91] \\
\hline & & Leaf extract & In vivo & Increased the platelet counts & [77] \\
\hline & & Leaf juice & Human & Increased the platelet counts & [93] \\
\hline & & Leaves & In vivo & Increased the platelet count and decreased the clotting time in rats & [76] \\
\hline & & Leaf juice & Human & Increased the platelet counts & [95] \\
\hline & & Leaf juice & In vivo & Increased the platelet counts & [78] \\
\hline & & Leaf juice & Human & Increased the platelet counts & [94] \\
\hline & & Leaves & In vivo & Increased the plasma CCL2/MCP-1 level & [82] \\
\hline & & Leaves & Human & Increased the platelet counts & [96] \\
\hline \multirow{2}{*}{$\begin{array}{l}\text { Cissampelos pareira } \\
\text { Cladogynos orientalis }\end{array}$} & Menispermacea & Aerial part & Human & Increased the platelet counts & [100] \\
\hline & Euphorbiaceae & Whole plant & In vitro & Inhibited DENV-1-4 replication & [87] \\
\hline Curcuma longa & Zingiberacea & Not stated & $\begin{array}{l}\text { In vitro } \\
\text { in vivo }\end{array}$ & $\begin{array}{l}\text { Anti-DENV activity in Huh7it-1 cells }\left(\mathrm{IC}_{50} 17.91=\mu \mathrm{g} / \mathrm{mL}\right) \\
\text { Anti- DENV-2 and reduce viremia period }\end{array}$ & [80] \\
\hline \multirow{3}{*}{$\begin{array}{l}\text { Cymbopogon citratus } \\
\text { Distictella elongata }\end{array}$} & Poaceae & Root & In vitro & Inhibited DENV-2 replication $(98.9 \%$ at a dose of $20 \mu \mathrm{g} / \mathrm{mL})$ & [86] \\
\hline & Bignoniaceae & $\begin{array}{l}\text { Leaves, stems } \\
\text { and fruits }\end{array}$ & In vitro & Anti-DENV-2 activity $\left(\mathrm{EC}_{50}=9.8 \mu \mathrm{g} / \mathrm{mL}\right)$ & {$[101]$} \\
\hline & & $\begin{array}{l}\text { Leaves } \\
\text { Whole plant }\end{array}$ & $\begin{array}{l}\text { In vivo } \\
\text { In vivo }\end{array}$ & $\begin{array}{l}\text { DENV-2 inhibition by } 34.7 \% \\
\text { Increased the platelet counts }\end{array}$ & $\begin{array}{l}{[15]} \\
{[77]}\end{array}$ \\
\hline \multirow[t]{3}{*}{ Euphorbia hirta } & Euphorbiaceae & Whole plant & In vitro & $\begin{array}{l}\text { Significantly reduced the plaque forming capacity of the DENV-1-2 } \\
\text { (85\% and } 90 \% \text { respectively) }\end{array}$ & {$[90]$} \\
\hline & & Leaves & In vitro & Inhibited DENV-2 replication $(34.7 \%$ at $20 \mu \mathrm{g} / \mathrm{mL}$ dose $)$ & [102] \\
\hline & & Whole weed & Human & Increased the platelet counts & [97] \\
\hline \multirow[t]{2}{*}{ Eurycoma longifolia } & Simaroubaceae & Root & In vitro & $\begin{array}{c}\text { Inhibited DENV-1, DENV-2, DENV-3 and DENV-4 }\left(\mathrm{IC}_{50}=33.84,33.55\right. \\
58.35 \text { and } 119 \mu \mathrm{g} / \mathrm{mL} \text {, respectively })\end{array}$ & [79] \\
\hline & & & In vivo & $\begin{array}{c}30 \% \text { lower viral load and } 12 \% \text { higher platelet count compared to the } \\
\text { control group }\end{array}$ & \\
\hline Flacourtia ramontchi & Salicaceae & Stem barks & In vitro & $\begin{array}{l}\text { Inhibited DENV-2 NS5 polymerase activity (89\% inhibition at } \\
10 \mu \mathrm{g} / \mathrm{mL})\end{array}$ & [103] \\
\hline \multirow{4}{*}{$\begin{array}{l}\text { Flagellaria indica } \\
\text { Faramea bahinensis } \\
\text { Faramea hyacinthina } \\
\text { and Faramea truncata } \\
\text { Faramea bahinensis, } \\
\text { Faramea hyacinthina } \\
\text { and Faramea truncata }\end{array}$} & Flagellariaceae & Whole plant & In vitro & Inhibited DENV-2 $(45.52 \%$ at a dose of $12.5 \mu \mathrm{g} / \mathrm{mL})$ & {$[87]$} \\
\hline & Rubiaceae & Leaves & In vitro & Anti-DENV activity in HEPG2 (100\% reduction in viral load) & [104] \\
\hline & Rubiaceae & Leaves & In vitro & Anti-DENV activity in HEPG2 (90 to $100 \%$ at a dose of $50 \mu \mathrm{g} / \mathrm{mL}$ ) & {$[105]$} \\
\hline & Rubiaceae & $\begin{array}{l}\text { Leaves and } \\
\text { stem }\end{array}$ & In vitro & Anti-DENV activity in HEPG2 (70 to $93 \%$ at a dose of $50 \mu \mathrm{g} / \mathrm{mL}$ ) & [106] \\
\hline Hippophae rhamnoides & Elaeagnaceae & Leaves & Human & $\begin{array}{l}\text { Anti-DENV activity in BHK-21 cells }(1 \mathrm{PFU} / \mathrm{mL} \text { at a dose of } 50 \\
\mathrm{mg} / \mathrm{mL}) \text {, decreased TNF- } \alpha \text { and increased IFN- } \gamma\end{array}$ & {$[107]$} \\
\hline \multirow[b]{2}{*}{ Houttuynia cordata } & \multirow[b]{2}{*}{ Saururaceae } & \multirow{4}{*}{$\begin{array}{l}\text { Whole plant } \\
\text { Aerial stem } \\
\text { and leaves } \\
\text { Aerial leaves } \\
\text { Leaves }\end{array}$} & In vitro & Inhibited DENV-2 replication $(35.99 \%$ at a dose of $1.56 \mu \mathrm{g} / \mathrm{mL})$ & [87] \\
\hline & & & In vitro & Inhibited the intracellular viral RNA replication $\left(\mathrm{EC}_{50}=0.8 \mu \mathrm{g} / \mathrm{mL}\right)$ & {$[36]$} \\
\hline & & & In vitro & Inhibited DENV-2 replication $\left(\mathrm{IC}_{50}=0.98 \mathrm{mg} / \mu \mathrm{L}\right)$ & {$[108,109]$} \\
\hline Ipomea batata & Convolvulaceae & & In vivo & Significant platelet increasing activity & [77] \\
\hline Justicia adhatoda & Acanthaceae & & In vitro & $\begin{array}{l}\text { Inhibited the growth of Vero cells infected with DENV-2 at a dose of } \\
\qquad 60 \mu \mathrm{g} / \mathrm{m}\end{array}$ & [110] \\
\hline Piper retrofractum & Piperaceae & Whole plant & In vitro & Inhibited DENV-2 replication $(84.93 \%$ at a dose of $100 \mu \mathrm{g} / \mathrm{mL})$ & [87] \\
\hline \multirow{2}{*}{ Psidium guajava } & \multirow{2}{*}{ Myrtaceae } & Bark & In vitro & Inhibited DENV-2 replication & [111] \\
\hline & & Leaves & In vitro & Inhibited DENV-2 replication at a dose of $60 \mu \mathrm{g} / \mu \mathrm{L}$ & [110] \\
\hline Phyllanthus sp & Phyllanthaceae & Whole plant & In vitro & Inhibited DENV-2 replication $(91.48 \%$ at a dose of $250 \mu \mathrm{g} / \mathrm{mL})$ & [49] \\
\hline Myristica fragrans & Myristicaceae & Leaves & In vitro & Inhibited DENV-2 replication $(122.7 \%$ at a dose of $20 \mu \mathrm{g} / \mathrm{mL})$ & [86] \\
\hline Quersus lucitanica & Fagaceae & Seed & In vitro & Inhibited DENV-2 $(100 \%$ at a dose of $0.032 \mathrm{mg} / \mathrm{mL})$ & [112] \\
\hline Rhizophora apiculata & Rhizophoraceae & Whole plant & In vitro & Inhibited DENV-2 replication ( $56.14 \%$ at a dose of $12.5 \mu \mathrm{g} / \mathrm{mL})$ & [87] \\
\hline Spondias mombin $\mathcal{E}$ & Anacardiaceae & Leaves juice & In vitro & Inhibited DENV-2 replication $(3.31 \%$ at a dose of $500 \mu \mathrm{g} / \mu \mathrm{L})$ & [85] \\
\hline Spondias tuberosa & Anacardiaceae & Leaves juice & In vitro & Inhibited DENV-2 replication ( $99 \%$ at a dose of $50017.98 \mu \mathrm{g} / \mathrm{mL})$ & [85] \\
\hline Uncaria tomentosa & Rubiaceae & Stem barks of & In vitro & Reducing DENV-Ag+ cell rates & [113] \\
\hline Annona muricata & Annonaceae & Fruit & In vitro & Inhibited DENV-2 replication $(99 \%$ at a dose of $1.25 \mathrm{mg} / \mathrm{mL})$ & [114] \\
\hline Catharanthus roseus & Apocynaceae & Leaves & In vitro & Inhibited DENV-2 replication ( $60 \%$ at a dose of $0.078 \mathrm{mg} / \mathrm{mL}$ ) & [115] \\
\hline Cynometra cauliflora & Fabaceae & Leaves & In vitro & Inhibited DENV-2 replication ( $78 \%$ at a dose of $12.5 \mathrm{mg} / \mathrm{mL})$ & [116] \\
\hline Orthosiphon stamineus & Lamiaceae & Leaves & In vitro & Inhibited DENV-2 replication ( $88 \%$ at a dose of $0.31 \mathrm{mg} / \mathrm{mL})$ & [117] \\
\hline
\end{tabular}

Abbreviations: $\mathrm{EC}_{50}$, median effective concentration; $\mathrm{IC}_{50}$, median inhibitory concentration; DENV, dengue virus; PFU, plaque forming units. 


\subsection{Anti-Dengue Bioactive Components from Medicinal Plants}

The bioactive constituents reported here showed different degrees of inhibitory activities against different serotypes of DENV. The isolated constituents belong to various chemical classes such as glycosylated and non-glycosylated polyphenols including flavonoids, sulfated polysaccharides, alkaloids, quinones, and terpenoids. Antiviral activity of andrographolide, a diterpene isolated from Andrographis paniculata showed significant inhibitory activity against DENV-2 in HepG2 and HeLa cell lines with EC 50 of 21.304 and $22.739 \mu \mathrm{M}$, respectively [118]. The compound also possessed larvicidal activity, which effectively increased the percentage of A. aegypti larvae mortality, concentration-dependently [119]. This property might be useful for the management of dengue vector.

A total of 51 bioactive compounds obtained from various plant sources were reported in this article to exhibit different degrees of anti-dengue activity. These compounds comprise six terpenoids, four phenolic acids, two alkaloids, a saponin, seven polysaccharides, 14 flavonoids, and 17 phenolics and flavonoid glycosides and derivatives. Plaque- and focus-forming assays used in in vitro studies are the major techniques for determining antidengue activity of potential compounds. Both assays are run to quantify the viral titer. The former is used to ascertain the number of DENV infectious particles (virions) by the means of plaque formation, while the latter is a variation of the former assay, which employs an immunostaining technique. The assay quantifies infected host cells and infectious DENV virions before the formation of a plaque after DENV-induced cell lysis.

Castanospermine, an alkaloid derived from black bean (Castanospermine australe), was investigated against all serotypes in vitro via plaque-forming assay using BHK-21 cells and in vivo using A/J mice. The compound inhibited all serotype infections in vitro at the level of secretion and infectivity, but could only inhibit DENV-2 in vivo and prevented mouse mortality [120]. These findings suggest that not all compounds that are active in in vitro studies would give similar outcomes in in vivo studies, more so in clinical studies. The percentage of inhibitory activity of these compounds ranged from 20-70\%, with phenolics and flavonoid glycosides and derivatives exhibiting the highest activity. Many of the compounds are selective in their anti-dengue activity against different serotypes. Most of them displayed activity against DENV-2. Quercetin and quercetirin obtained from the ethyl acetate fraction of $H$. cordata aerial leaves displayed anti-DENV-2 effects with median inhibitory concentration $\left(\mathrm{IC}_{50}\right)$ of $176.76 \mu \mathrm{g} / \mathrm{mL}$ and $467.27 \mu \mathrm{g} / \mathrm{mL}$, respectively, showing a bigger virucidal effect of quercetin than its glycoside, quercetirin. However, the quercetin was more cytotoxic $\left(\mathrm{CC}_{50}=155.38 \mu \mathrm{g} / \mathrm{mL}\right)$ than the quercetirin [108]. In another study, four constituents from the ethyl acetate fraction of the same plant-chlorogenic acid, hyperoside, quercetin, and quercetirin-were tested against the NGC strain of DENV-2 using the plaque reduction assay individually displayed certain degrees of activity, while their combination yielded greater antiviral effects [109]. The main phenolic constituents of Spondias mombin and Spondias tuberosa-rutin, quercetin and ellagic acid-showed antiviral effects at $500 \mu \mathrm{g} / \mathrm{mL}$ and inhibited viral replication by $68.42 \%, 50 \%$, and $25.02 \%$, respectively in C6/36 cells. Rutin was the most active [85]. Among the compounds purified from the methanol extract of yellow rhizomes of Boesenbergia rotunda and tested against DENV-2, four compounds exhibited anti-DENV activity. These compounds were chalcone derivatives: 4-hydroxypanduratin A, panduratin A, pinostrobin, and cardamonin. The first two compounds exhibited good competitive inhibitory activity toward DENV NS3 protease, while the last two compounds demonstrated non-competitive inhibitory activity [37].

Fucoidan, a sulfated polysaccharide isolated from Cladosiphon okamuranus (marine alga) inhibited DENV-2 infection tested in BHK-21 cells using the focus-forming assay. The compound reduced infectivity by $20 \%$ at a concentration of $10 \mu \mathrm{g} / \mathrm{mL}$. However, based on the structure-activity relationship, conversion of glucuronic acid-a residue present in the fucoidan-to glucose resulted in the loss of the compound inhibitory activity, suggesting its critical involvement in fucoidan antiviral function, whereas removal of the sulfated functional group resulted in the attenuation of DENV-2 infection similar to that of fucoidan $(21 \%)$. This suggests that the sulfated group does not have any significant effect on antiviral 
activity against DENV-2 infection [121]. Another sulfated polysaccharide, galactans isolated from Cryptomenia crenulata [122] and Gymnogongrus tolulosus [123], were reported to inhibit DENV-2 replication in Vero cells with $\mathrm{IC}_{50}$ of $1.0 \mu \mathrm{g} / \mathrm{mL}$ and $0.19-1.7 \mu \mathrm{g} / \mathrm{mL}$, respectively. Galactan obtained from C. crenulata has selective activity. The compound was reported to be totally inactive against DENV-1, but exhibited good inhibitory effects against DENV-2 and DENV-3, but displayed weak effect on DENV-4 [122], where the protective effects could be via inhibition of the virus adsorption or virus internalization [124]. Another isolated sulfated polysaccharide called kappa-carrageenan from Gymnogongrus griffithsiae selectively inhibited DENV-2 replication $\left(\mathrm{IC}_{50}=0.9 \mu \mathrm{g} / \mathrm{mL}\right)$, but exhibited lower effects against DENV-3, and was totally inactive against DENV-1 and DENV-4. This compound was also obtained from Meristiella gelidium and exhibited anti-DENV-2 activity with $\mathrm{IC}_{50}$ between $0.14-1.6 \mu \mathrm{g} / \mathrm{mL}$ [125]. The findings suggest that both sulfated polysaccharides have the potential to be developed as anti-DENV-2 and anti-DENV-3 drugs.

Many other compounds isolated from various plants that display anti-DENV activities are shown in Table 3. To date, antiviral agents for DENV that have been developed act by inhibiting viral entry, RNA-dependent RNA polymerase (RdRp), protease, or helicase enzymes (Figure 2) [126]. So far, the plant compounds purified from trunk bark of Crypotocarya chartacea, mono- and dialkylated flavanones (chartaceones 1-6) have shown remarkable non-structural protein 5 (NS5) RdRp inhibitory activity with $\mathrm{IC}_{50}$ ranging from 1.8 to $4.2 \mu \mathrm{M}$ [127]. Purified daphane diterpenoid orthoesters from the barks and woods of Trigonostemon cherrieri-trigocherrins A and trigocherriolides B and C-also inhibited DENV RdRp, while no effect was seen with trigocherrins B and F as well as trigocherriolide A [128]. No plant compounds with anti-DENV property that could act via helicase and protease inhibitory activities have been reported. Most of the studies are still at the stage of activity screening. More works need to be done to explore the anti-DENV potential with their mechanism such as the inhibition of viral genomes and the destruction of enzymes necessary for viral encoding to find potential candidates for DENV treatment.

Table 3. Isolated compound with bioactivity against DENV infection.

\begin{tabular}{|c|c|c|c|c|}
\hline Compound & Class of Compound & Plant Source & Antiviral Effects & Reference \\
\hline \multirow[t]{4}{*}{ Andrographolide } & Diterpenoid & Andrographis paniculata & $\begin{array}{c}\text { Anti-DENV activity in HepG2 }\left(E_{50}=21.304 \mu \mathrm{M}\right) \text { and HeLa cell } \\
\text { lines }\left(E_{50}=22.739 \mu \mathrm{M}\right)\end{array}$ & [118] \\
\hline & & & $\begin{array}{c}\text { Good anti-DENV effects in both visual }\left(\mathrm{EC}_{50}=0.56 \mu \mathrm{g} / \mathrm{mL}\right) \text { and } \\
\text { neutral red cytopathic effects }\left(\mathrm{EC}_{50}=0.58 \mu \mathrm{g} / \mathrm{mL}\right)\end{array}$ & [129] \\
\hline & & & $\begin{array}{c}\text { Reduced mean number of } A \text {. aegypti eggs and increased larvae } \\
\text { mortality concentration-dependently }\end{array}$ & [119] \\
\hline & & & $\begin{array}{l}\text { Delayed disease onset, reduced mortality and DENV-1, DENV-2, } \\
\text { DENV-3 and DENV-4 loads in infected mouse brains }\end{array}$ & [130] \\
\hline Apiofuranoside & Flavanone glycosides & Faramea bahiensis & $\begin{array}{l}\text { Controlled viral replication and reduced numbers of infected } \\
\text { cells }(12 \%) \text { and RNA copies of DENV-2 (67\%) in HepG2 cells }\end{array}$ & [104] \\
\hline Betulinic acid 3ß-caffeate & Phenyl terpenoid & Flacourtia ramontchi & $\begin{array}{l}\text { Inhibited DENV replication } \\
\quad\left(\mathrm{IC}_{50}=0.85 \mu \mathrm{M}\right)\end{array}$ & [103] \\
\hline Caffeoylcalleryanin & Phenolic glycoside & Arrabidaea pulchra & $\begin{array}{l}\text { Anti-DENV-2 activity } \\
\left(\mathrm{IC}_{50}=2.8 \mu \mathrm{g} / \mathrm{mL}\right)\end{array}$ & {$[84]$} \\
\hline Cardamonin & Phenolic & Boesenbergia rotunda & Non-competitive anti-DENV activity & [37] \\
\hline Castanospermine & Alkaloid & Castanospermine australe & $\begin{array}{l}\text { Inhibited secretion and infectivity in all DENV serotypes in vitro. } \\
\text { Only inhibited DENV-2 in vivo and prevented mouse mortality. }\end{array}$ & [120] \\
\hline Chartaceones 1 & Dialkylated flavanone & Crypotocarya chartacea & $\begin{array}{c}\text { Inhibited NS5 RdRp } \\
\left(\mathrm{IC}_{50}=14.8 \mu \mathrm{M}\right)\end{array}$ & [127] \\
\hline Chartaceones 2 & & & $\begin{array}{l}\text { Inhibited NS5 RdRp } \\
\quad\left(\mathrm{IC}_{50}=72.7 \mu \mathrm{M}\right)\end{array}$ & [127] \\
\hline Chartaceones 3 & & & $\begin{array}{l}\text { Inhibited NS5 RdRp } \\
\quad\left(\mathrm{IC}_{50}=4.2 \mu \mathrm{M}\right)\end{array}$ & [127] \\
\hline Chartaceones 4 & & & $\begin{array}{l}\text { Inhibited NS5 RdRp } \\
\quad\left(\mathrm{IC}_{50}=1.8 \mu \mathrm{M}\right)\end{array}$ & [127] \\
\hline Chartaceones 5 & & & $\begin{array}{l}\text { Inhibited NS5 RdRp } \\
\quad\left(\mathrm{IC}_{50}=2.9 \mu \mathrm{M}\right)\end{array}$ & [127] \\
\hline Chartaceones 6 & & & $\begin{array}{l}\text { Inhibited NS5 RdRp } \\
\quad\left(\mathrm{IC}_{50}=2.4 \mu \mathrm{M}\right)\end{array}$ & [127] \\
\hline Chlorogenic acid & Phenolic acid & Houttuynia cordata & $\begin{array}{c}\text { Synergistic antiviral effect of combined hyperoside and } \\
\text { chlorogenic acid }\end{array}$ & [109] \\
\hline Ellagic acid & Phenolic acid & $\begin{array}{l}\text { Spondias mombin and } \\
\text { Spondias tuberosa }\end{array}$ & Anti-DENV-2 (25\%) at $500 \mu \mathrm{g} / \mathrm{mL}$ & [85] \\
\hline Flacourtoside A & Phenolic glycoside & Flacourtia ramontchi & $\begin{array}{l}\text { Inhibited DENV replication } \\
\qquad\left(\mathrm{IC}_{50}=9.3 \mu \mathrm{M}\right)\end{array}$ & [103] \\
\hline
\end{tabular}


Table 3. Cont

\begin{tabular}{|c|c|c|c|c|}
\hline Compound & Class of Compound & Plant Source & Antiviral Effects & Reference \\
\hline Flacourtoside B & & & $\begin{array}{l}\text { Inhibited DENV replication } \\
\qquad\left(\mathrm{IC}_{50}=71.1 \mu \mathrm{M}\right)\end{array}$ & \\
\hline Flacourtoside C & & & $\begin{array}{l}\text { Inhibited DENV replication } \\
\qquad\left(\mathrm{IC}_{50}=23.8 \mu \mathrm{M}\right)\end{array}$ & \\
\hline Flacourtoside D & & & $\begin{array}{l}\text { Inhibited DENV replication } \\
\qquad\left(\mathrm{IC}_{50}=35.5 \mu \mathrm{M}\right)\end{array}$ & \\
\hline Flacourtoside E & & & $\begin{array}{l}\text { Inhibited DENV replication } \\
\qquad\left(\mathrm{IC}_{50}=13.4 \mu \mathrm{M}\right)\end{array}$ & \\
\hline Flacourtoside F & & & $\begin{array}{l}\text { Inhibited DENV replication } \\
\qquad\left(\mathrm{IC}_{50}=39.8 \mu \mathrm{M}\right)\end{array}$ & \\
\hline Fucoidan & $\begin{array}{l}\text { Sulfated } \\
\text { polysaccharide }\end{array}$ & Cladosiphon okamuranus & $\begin{array}{l}\text { Inhibited DENV-2 Reduced infectivity by } 20 \% \text { at } 10 \mu \mathrm{g} / \mathrm{mL} \text { in } \\
\text { BHK-21 cells }\end{array}$ & [121] \\
\hline Galactan & $\begin{array}{l}\text { Sulfated } \\
\text { polysaccharide }\end{array}$ & Cryptomenia crenulate & $\begin{array}{c}\text { Inhibited DENV-2 and DENV-3 replication in Vero cells }\left(\mathrm{IC}_{50}=\right. \\
1.0 \mu \mathrm{g} / \mathrm{mL}) \text {, slight inhibitory effect against DENV-4, inactive } \\
\text { against DENV-1 }\end{array}$ & [122] \\
\hline & & Gymnogongrus tolulosus & $\begin{array}{l}\text { Inhibited DENV-2 and DENV-3 replication in Vero cells }\left(\mathrm{IC}_{50}=\right. \\
0.19-1.7 \mu \mathrm{g} / \mathrm{mL})\end{array}$ & [123] \\
\hline Galactomannan & Polysaccharride & Mimosa scabrella & Reduced DENV-1 titer 100-fold in C6/36 cells at 347 mg/L & [131] \\
\hline & & Leucaena leucocephala & Reduced DENV-1 titer 100-fold in C6/36 cells at $37 \mathrm{mg} / \mathrm{L}$ & [131] \\
\hline Glabranine & Flavanone & Tephrosia species & Anti-DENV (70\% inhibition) at $25 \mu \mathrm{M}$ & [132] \\
\hline Hyperoside & Flavonol glycoside & Houttuynia cordata & $\begin{array}{l}\text { Synergistic antiviral effect of combination of hyperoside and } \\
\text { chlorogenic acid }\end{array}$ & [109] \\
\hline 4-Hydroxy-panduratin A & Phenolic derivative & Boesenbergia rotunda & $\begin{array}{l}\text { Competitive inhibitory activity against DENV-2 NS3 protease } \\
\qquad\left(\mathrm{K}_{1}=21 \mu \mathrm{M}\right)\end{array}$ & [37] \\
\hline Kappa carrageenan & $\begin{array}{l}\text { Sulfated } \\
\text { polysaccharide }\end{array}$ & Gymnogongrus griffithsiae & $\begin{array}{c}\text { Selectivity inhibited DENV-2 }\left(\mathrm{IC}_{50}=0.9 \mu \mathrm{g} / \mathrm{mL}\right), \mathrm{DENV}-3 \text { and } \\
\text { DENV-4 replication. Inactive against DENV-1 }\end{array}$ & [122] \\
\hline & & Meristiella gelidium & Anti-DENV-2 activity $\left(\mathrm{IC}_{50}\right.$ between $\left.0.14-1.6 \mu \mathrm{g} / \mathrm{mL}\right)$ & [125] \\
\hline 7-O-methyl-glabranine & Flavanone & Tephrosia species & $\begin{array}{l}\text { Exhibited } 70 \% \text { inhibition on DENV in a plaque-forming assay at } \\
\qquad 25 \mu \mathrm{M}\end{array}$ & [132] \\
\hline Methyl gallate & Phenolic acid & Quercus lusitanica & Inhibited DENV-2 protease $(98 \%)$ at $0.3 \mathrm{mg} / \mathrm{mL}$ & [133] \\
\hline Palmatine & Alkaloid & Coptis chinensis & Inhibited DENV replication $\left(\mathrm{EC}_{50}=26.4 \mu \mathrm{mol} / \mathrm{L}\right)$ & [134] \\
\hline Panduratin A & Phenolic derivative & Boesenbergia rotunda & $\begin{array}{l}\text { Competitive inhibitory activity against DENV-2 NS3 protease } \\
\qquad\left(\mathrm{K}_{1}=25 \mu \mathrm{M}\right)\end{array}$ & [37] \\
\hline Pectolinarin & Flavone & Distictella elongate & $\begin{array}{l}\text { Good anti-DENV-2 effect } \\
\quad\left(\mathrm{EC}_{50}=86.4 \mu \mathrm{g} / \mathrm{mL}\right)\end{array}$ & [101] \\
\hline Pinostrobin & Flavanone & Boesenbergia rotunda & Non-competitive DENV replication inhibitory activity & [37] \\
\hline Quercetin & Flavonoid & Houttuynia cordata & Anti-DENV-2 effect at $500 \mu \mathrm{g} / \mathrm{mL}\left(\mathrm{IC}_{50}=176.76 \mu \mathrm{g} / \mathrm{mL}\right)$ & [108] \\
\hline Quercetin & Flavonol & Houttuynia cordata & $\begin{array}{l}\text { Synergistic antiviral effect of quercetirin and quercetin } \\
\text { combination }\end{array}$ & [109] \\
\hline \multirow{3}{*}{ Quercetirin } & \multirow{3}{*}{ Flavonoid glycoside } & $\begin{array}{l}\text { Spondias mombin and } \\
\text { Spondias tuberosa }\end{array}$ & Inhibited viral replication (50\%) of DENV-2 at $500 \mu \mathrm{g} / \mathrm{mL}$ & {$[85]$} \\
\hline & & Houttuynia cordata & $\begin{array}{l}\text { Exhibited less activity in an uncombined form compared to its } \\
\text { mixture with quercetin } \\
\left.\text { (IC } \mathrm{I}_{50}=467.27 \mu \mathrm{g} / \mathrm{mL}\right)\end{array}$ & [108] \\
\hline & & Houttuynia cordata & $\begin{array}{l}\text { Synergistic antiviral effect of quercetirin and quercetin } \\
\text { combination. greater antiviral effects }\end{array}$ & [109] \\
\hline Rutin & Flavonol glycoside & $\begin{array}{l}\text { Spondias mombin and } \\
\text { Spondias tuberosa }\end{array}$ & Inhibited viral replication of DENV-2 at $500 \mu \mathrm{g} / \mathrm{mL}$ by $68.42 \%$ & [85] \\
\hline Scolochinenoside D & Phenolic glycoside & Flacourtia ramontchi & $\begin{array}{l}\text { Inhibited DENV replication } \\
\qquad\left(\mathrm{IC}_{50}=9.5 \mu \mathrm{M}\right)\end{array}$ & [103] \\
\hline Trigocherrin A & Diterpenoid & Trigonostemon cherrieri & $\begin{array}{l}\text { Inhibited DENV replication } \\
\qquad\left(\mathrm{IC}_{50}=12.7 \mu \mathrm{M}\right)\end{array}$ & [128] \\
\hline Trigocherriolide B & Diterpenoid & Trigonostemon cherrieri & $\begin{array}{l}\text { Inhibited DENV replication } \\
\qquad\left(\mathrm{IC}_{50}=3.1 \mu \mathrm{M}\right)\end{array}$ & [128] \\
\hline Trigocherriolide C & Diterpenoid & Trigonostemon cherrieri & $\begin{array}{l}\text { Inhibited DENV replication } \\
\qquad\left(\mathrm{IC}_{50}=16.0 \mu \mathrm{M}\right)\end{array}$ & [128] \\
\hline Ursolic acid & Triterpenoid & Arrabidaea pulchra & $\begin{array}{l}\text { Displayed anti-DENV-2 } \\
\quad\left(\mathrm{IC}_{50}=3.2 \mu \mathrm{g} / \mathrm{mL}\right)\end{array}$ & [84] \\
\hline Verbascoside & Phenyl glycoside & Arrabidaea pulchra & $\begin{array}{l}\text { Displayed anti-DENV-2 } \\
\quad\left(\mathrm{IC}_{50}=3.4 \mu \mathrm{g} / \mathrm{mL}\right)\end{array}$ & [84] \\
\hline Baicalein & Bioflavonoid & Scutellaria baicalensis & $\begin{array}{l}\text { Displayed anti-DENV-2 } \\
\left(\mathrm{IC}_{50}=1.55 \mu \mathrm{g} / \mathrm{mL}\right)\end{array}$ & [135] \\
\hline Zosteric acid & Phenolic acid & Zostera marina & $\begin{array}{l}\text { Displayed anti-DENV-2 } \\
\quad\left(\mathrm{IC}_{50}=2.3 \mathrm{mM}\right)\end{array}$ & [136] \\
\hline
\end{tabular}

Abbreviations: $\mathrm{EC}_{50}$, median effective concentration; $\mathrm{IC}_{50}$, median inhibitory concentration; $\mathrm{DENV}$, dengue virus; $\mathrm{DENV}-1$, dengue virus type-1; DENV-2, dengue virus type 2, DENV-3, dengue virus type 3, DENV-4, dengue virus type 4, RdRp, RNA-dependent RNA polymerase; NS3, nonstructural protein 3.

Another aspect that could be investigated is the indirect effects of these compounds on the DENV biology. Studies have shown the involvement of oxidative stress and inflammation in DENV infectivity $[137,138]$. Most of the bioactive compounds that have anti-DENV activities are polyphenols and diterpenoids. These compounds have been abundantly reported to possess antioxidant and anti-inflammatory activities in many studies [139-141]. However, investigation of the medicinal plant antioxidant and anti-inflammatory effects on dengue fever pathogenesis is still lacking. Only a study by Tseng et al. [93] have studied 
this aspect. They reported that andrographolide induced heme oxygenase-1 (HO-1) activity, an antioxidant enzyme in mice that strongly delayed the disease onset and mortality by activating the antiviral host type- 1 interferon (IFN) response in an infected mice model as well as reduced DENV-1-4 loads in the infected mouse brains [130]. HO-1 is an enzyme that catalyzes the conversion of heme into carbon monoxide, biliverdin, and iron. It is known that HO-1 exhibits its cytoprotective effects through antioxidant effects [142,143]. This suggests that any therapy or drug capable of inducing the HO-1 signaling pathway could be a promising candidate of treating DENV infection.

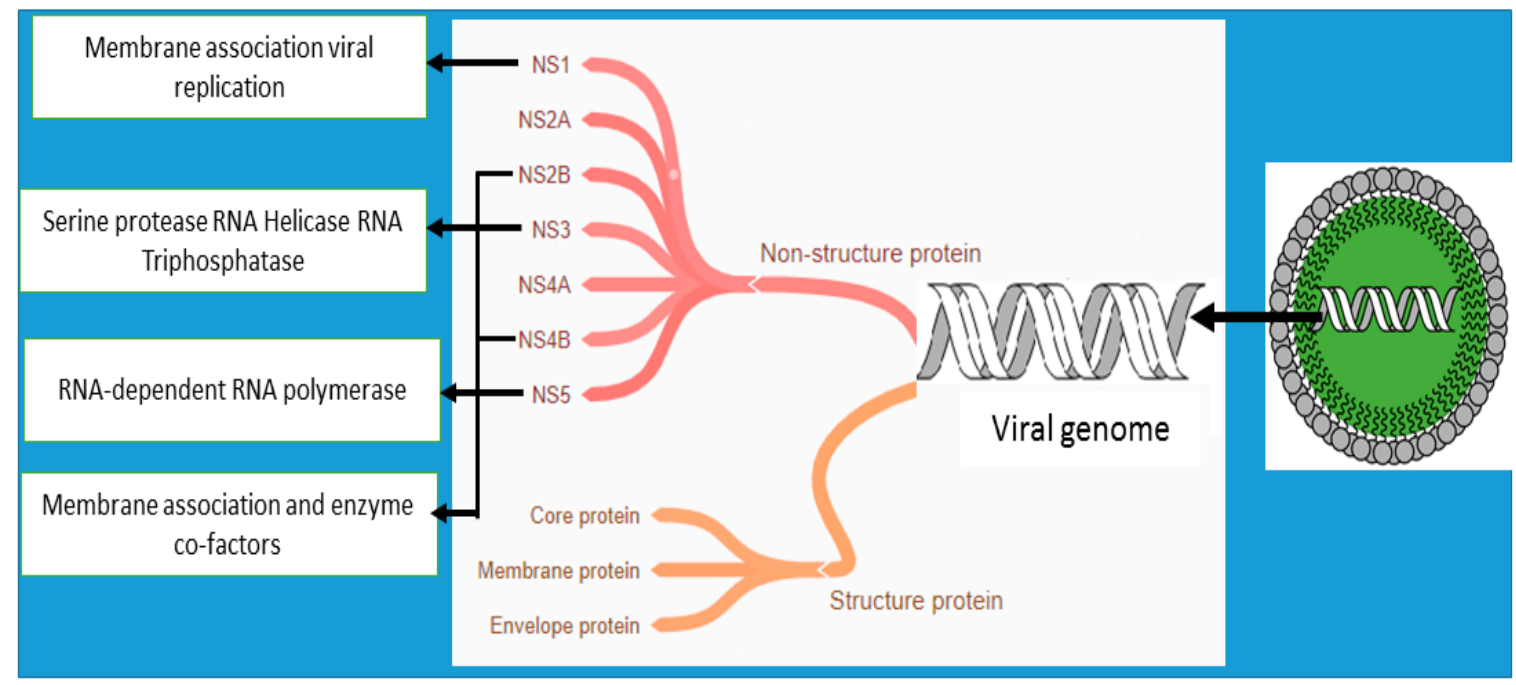

Figure 2. Diagrammatic representation of possible inhibitory sites against DENV.

\section{Potential Traditional Plants-Based Medicines for SARS-CoV-2 (COVID-19)}

For years, natural products from plant-based origin have been an indispensable source of medicinally active constituents that are essential for drug discovery and development for the treatment of numerous diseases. Many herbal medicines have been recognized to play a tremendous role in the treatment of emerging pandemics, specifically the ability to block the SARS virus from binding to its receptor, angiotensin-converting enzyme 2 (ACE-2) [144]. Increased ACE-2 activity and expression have been known to modulate the inflammatory cytokine levels, most notably interleukin-1 and high-mobility group box 1 (HMGB1). The presence of the glycan-mimicking structure in most bioactive compounds (especially phenolic compounds) makes them suitable for various protein-inhibitory roles [145]. One of the plant-based natural products is a traditional Chinese medicine approved for the treatment of the SARS-CoV outbreak in 2003 [146], leading to the employment of traditional Chinese medicine in the current COVID-19 treatment in China [147]. Furthermore, various herbal plants from different families have been investigated and proven to be efficacious in the treatment of this pandemic (Table 4). Water extract of the whole plant of Houttuynia coedata was reported to slow down viral replication through pivotal enzyme inhibition against SARS-CoV as a result of its ability to inhibit 3C-like protease (3CL ${ }^{\text {ro }}$ ) and $\operatorname{RdRp}$ of the virus [39]. Similar water extract of young leaves of Toona sinensis also exhibited good inhibitory effect against SARS-CoV and human coronavirus 229E (HCoV 229E) replication [148]. Anti-SARS-CoV activities of several other plant extracts such as ethanol extract of Euphoria nerifolia leaves [149], polar and non-polar extracts of Chinese's medicinal herbs such as Cibotium barometz, Gentiana scabra, Dioscorea batatas, Cassia tora, and Taxillus chinensis [150], water extract of Istatis indigotica root [151], and ethyl acetate soluble fraction of Angelica keiskei [152] were also reported. Thus far, neither in vivo nor clinical studies involving herbal medicines and SARS-CoV have been reported. 
Table 4. Medicinal plants with anti-SARS-CoV activity.

\begin{tabular}{|c|c|c|c|c|c|}
\hline Species & Family & Part Used & $\begin{array}{l}\text { Type of } \\
\text { Study }\end{array}$ & Mode of Action & Reference \\
\hline Boesenbergia rotunda & Zingiberaceae & $\begin{array}{c}\text { Rhizome } \\
\text { ethanol extract }\end{array}$ & In vitro & Suppressed SARS-CoV-2 infectivity in Vero E6 cells & [38] \\
\hline $\begin{array}{l}\text { Broussonetia } \\
\text { papyrifera }\end{array}$ & Moraceae & Roots & In vitro & Chloroform fraction inhibited viral replication & [153] \\
\hline Euphoria nerifolia & Euphorbiaceae & Leaves & In vitro & Exhibited antiviral activity against SARS-CoV & [149] \\
\hline Toona sinensis & Meliaceae & $\begin{array}{l}\text { Tender leaf } \\
\text { extract }\end{array}$ & In vitro & Inhibited SARS-CoV replication & [148] \\
\hline Gentiana scabra & Gentianaceae & Rhizomes & & Inhibited viral replication of SARS-CoV in Vero E6 cells & [150] \\
\hline Dioscorea batatas & Dioscoreaceae & Tubers & In vitro & Inhibited viral replication of SARS-CoV in Vero E6 cells & [150] \\
\hline Cassia tora & Caesalpinioideae & Dried seeds & In vitro & Inhibited viral replication of SARS-CoV in Vero E6 cells & [150] \\
\hline Taxillus chinensis & Loranthaceae & $\begin{array}{l}\text { Dried stems } \\
\text { and leaves }\end{array}$ & In vitro & Inhibited viral replication of SARS-CoV in Vero E6 cells & [150] \\
\hline Cibotium barometz & Cibotiaceae & Rhizomes & In vitro & Inhibited viral replication of SARS-CoV in Vero E6 cells & {$[150]$} \\
\hline Cinnamomi verum & Lauraceae & $\begin{array}{l}\text { Butanol } \\
\text { fraction }\end{array}$ & In vitro & Inhibited wild type SARS-CoV & [154] \\
\hline Houttuynia cordata & Saururaceae & $\begin{array}{l}\text { Dried whole } \\
\text { plant }\end{array}$ & & $\begin{array}{c}\text { Had antiviral activity against SARS-CoV via inhibition } \\
\text { on 3CL pro and RNA-dependent RNA polymerase of } \\
\text { the virus }\end{array}$ & [39] \\
\hline IsatisIndigotica & Cruciferae & $\begin{array}{c}\text { Root water } \\
\text { extract }\end{array}$ & In vitro & Inhibited the cleavage activity of SARS 3CL ${ }^{\text {pro }}$ enzyme & [151] \\
\hline
\end{tabular}

Abbreviations: SARS-CoV-2, severe acute respiratory syndrome coronavirus-2; SARS-CoV, severe acute respiratory syndrome coronavirus; 3CL ${ }^{\text {pro }}$, 3C-like protease.

Phenolic compounds, especially flavonoids, have been identified as suitable candidates for binding and inhibiting ACE-2 and SARS-CoV-2 S protein through in silico crystal structure modeling [155]. Quercetin obtained from different plant sources has been reported in different studies to inhibit SARS-CoV-related infection. Its purified compound from the tender leaf extract of Toona sinensis was reported to inhibit cellular entry of SARS$\mathrm{CoV}$ and prevent viral replication [148]. Luteolin from Chinese herbs exhibits significant anti-SARS-CoV activity with $50 \%$ efficacy at a concentration of $4.5 \mu \mathrm{M}$ [156]. Scutellarein, obtained from Scutettaria baicalensis and Asplenium belangeri as well as myricetin from Myrica rubra inhibit the ATPase activity of SARS-CoV helicase nsP13 [157]. Inhibition of this enzyme is another therapeutic option for coronaviruses because it results in inhibition of viral replication [158].

Trans-(3,5, '-trihydroxystilbene), a major compound present in abundance in Polygonum cuspidatum, Vitis vinifera, and Vaccinium macrocarpon, which exhibits inhibitory activity against MERS-CoV infection [159]. Other polyphenols with inhibitory activity against SARS-CoV include gallocatechin gallate, procyanidin B1 [154], and kaempferol [153], which have been investigated in vitro and proven to effectively treat SARS-CoV and MERS-CoV infections. Other compounds reported with anti-SARS-CoV (Table 5) include an alkaloid called lycorine purified from Lycoris radiate [160], glycyrrhizin, a saponin isolated from the root of Glycyrrhiza glabra [161], tetra-O-galloyl-ß-D-glucose, the major component of Galla chinensis [156], sinigrin, indigo emodin, and hesperetin from water extract of Istatis indigotica [151]. Emodin from Rheum and Polygonum genera blocks the SARS-CoV spike protein and ACE interaction in order to prevent SARS-CoV invasion [162] and inhibits SARS-associated coronavirus 3a protein [163].

Among the antiviral effects of the plant-based bioactive compounds are papain-like protease $\left(\mathrm{PL}^{\mathrm{pro}}\right)$ and $3 \mathrm{CL}^{\text {pro }}$ inhibitions. Both proteases are crucial in the viral life cycle. Therefore, inhibition of these proteases observed in many medicinal plants would then curb the viral replication. $3 \mathrm{CL}^{\text {pro }}$ is a major protease in coronavirus. It is involved in catalytic cleavage of the viral polyproteins at 11 cleave sites, producing 12 individual viral proteins which then form functional complexes essential in viral replication [164]. Biflavonoids like amentoflavone, apigenin, and luteolin, purified from Torreya nucifera, inhibit 3CL ${ }^{\text {pro }}$ function [165]. Polyphenols purified from the most active chloroform fraction of Broussonetia papyrifera roots selectively exhibit higher inhibitory activity against PL pro than $3 \mathrm{CL}^{\text {pro }}$, and papyriflavonol is among the compounds that has the highest inhibitory 
effects on PL ${ }^{\text {pro }}$ with an $\mathrm{IC}_{50}$ value of $3.7 \mu \mathrm{M}$ [153]. Xanthoangelol, an alkylated chalcone isolated from the ethyl acetate soluble fraction of Angelica keiskei leaves, is also active against both $3 \mathrm{CL}^{\text {pro }}$ and $\mathrm{PL}^{\text {pro }}$ with $\mathrm{IC}_{50}$ values of 11.4 and $1.2 \mu \mathrm{M}$, respectively [152]. Diarylheptanoid compounds isolated from the ethanol extract of Alnus japonica barks also exhibited dose-dependent inhibitory effects against PL ${ }^{\text {pro }}$. Among the compounds, hirsutenone showed the highest effect with $\mathrm{IC}_{50}$ of $4.1 \mu \mathrm{M}$ [166]. In another study, sinigrin, indigo emodin, and hesperetin isolated from the water extract of Istatis indigotica inhibited $3 \mathrm{CL}^{\text {pro }}$ of SARS-CoV via cell-based cleavage and cell-free cleavage assays [151]. Cell-free cleavage assay is an enzyme immunoassay to detect anti-3CL pro effect by the plant extract. In this assay, viral purified recombinant $3 C^{\text {pro }}$ expressed in $E$. coli is incubated with a substrate fusion protein (cleavage substrate) and plant extract before the detection of noncleavage substrate protein using enzyme immunoassay. On the other hand, purification of $3 \mathrm{CL}^{\text {pro }}$ is not necessary in a cell-based assay. Plasmid that carries $3 \mathrm{CL}^{\text {pro }}$, cleavage substrate, and luciferase is co-transfected with a vector like pEGFP-N into cells, and then later the luciferase activity is determined to estimate the cleavage by the viral $3 \mathrm{CL}^{\text {pro }}$ [151]. Based on these reports, it seems that the isolated polyphenols displayed greater suppression on PL ${ }^{\text {pro }}$ than on $3 C^{\text {pro }}$ to exert their anti-SARS-CoV effects, suggesting that these compounds may be effective in inhibiting coronavirus replication.

Moreover, many plant-based lectins have also been reported to demonstrate significant inhibitory activities against coronaviruses. Thirty-three lectins purified from different plant species were screened against SARS-CoV and feline coronavirus (FCoV). Mannosebinding lectin was identified to possess a notable anti-coronavirus activity by targeting the entry and the release of virus particles [167]. Agglutinin isolated from Galanthus nivalis was also reported to remarkably inhibit $\mathrm{FCoV}$ when administered in combination with nelfinavir, a synthetic antiretroviral drug [168]. These plant-derived constituents could be potential drug candidates for the treatment of SARS-CoV infection. Figure 3 depicts the possible specific target receptors and proteins in SARS-CoV that could be modulated by medicinal plants and their phytoconstituents. Another possible target is the type II transmembrane serine protease 2 (TMPRSS2). It can cleave the coronaviral receptor ACE-2 to amplify infectivity as well as activate the viral spike protein for membrane fusion [169]. Similar to DENV studies, no reports have been published regarding the antioxidant and anti-inflammatory effects of the medicinal plants on SARS-CoV infectivity, even though oxidative stress and inflammation have been demonstrated to play significant roles in the disease progression [170]. It is strongly believed that medicinal compounds with good antioxidant and anti-inflammatory properties might reduce or prevent the disease severity.

Table 5. Isolated compounds with anti-SARS-CoV activities.

\begin{tabular}{|c|c|c|c|}
\hline Plant Source & Compounds & Mode of Action & Reference \\
\hline $\begin{array}{c}\text { Boesenbergia. } \\
\text { rotunda }\end{array}$ & Panduratin & Inhibited SARS-CoV-2 in E6 cells & [38] \\
\hline Angelica keiskei & Xanthoangelol & Inhibited PL ${ }^{\text {pro }}$ in vitro & [152] \\
\hline Alnus japonica & Hirsutenone & Inhibited PL ${ }^{\text {pro }}$ in vitro & [166] \\
\hline \multirow{11}{*}{$\begin{array}{c}\text { Broussonetia } \\
\text { papyrifera }\end{array}$} & Hirustanonol & Inhibited PL ${ }^{\text {pro }}$ in vitro & [166] \\
\hline & Oregonin & Inhibited PL ${ }^{\text {pro }}$ in vitro & [166] \\
\hline & Rubranol & Inhibited PL ${ }^{\text {pro }}$ in vitro & [166] \\
\hline & Rubraanoside & Inhibited PL ${ }^{\text {pro }}$ in vitro & [166] \\
\hline & Rubranoside A & Inhibited PL ${ }^{\text {pro }}$ in vitro & [166] \\
\hline & Broussochalcone B & Inhibited PL pro better than $3 C L^{\text {pro }}$ & [153] \\
\hline & Broussochalcone A & Inhibits PL pro higher than $3 C^{\text {pro }}$ & [153] \\
\hline & 4-Hydroxyisolonchocarpin & Inhibited PL pro better than 3CL pro & [153] \\
\hline & Kazinol & Inhibited PL ${ }^{\text {pro }}$ better than $3 C^{\text {pro }}$ & [153] \\
\hline & Kazinol A & Inhibited PL pro better than $3 C^{\text {pro }}$ & [153] \\
\hline & Kazinol B & Inhibited PL pro better than $3 C^{\text {pro }}$ & [153] \\
\hline
\end{tabular}


Table 5. Cont.

\begin{tabular}{|c|c|c|c|}
\hline Plant Source & $\begin{array}{l}\text { Kazinol F } \\
\text { Compounds }\end{array}$ & $\begin{array}{l}\text { Inhibited PL pro better than 3CL pro } \\
\text { Mode of Action }\end{array}$ & $\begin{array}{c}{[153]} \\
\text { Reference }\end{array}$ \\
\hline \multirow[b]{4}{*}{$\begin{array}{l}\text { Cinnamomic } \\
\text { verum }\end{array}$} & Kazinol J & Inhibited PL ${ }^{\text {pro }}$ better than $3 \mathrm{CL}^{\text {pro }}$ & [153] \\
\hline & 3'-(3-methylbut-2-enyl)-3', & Inhibited PL pro better than $3 C^{\text {pro }}$ & [146] \\
\hline & Papyriflavonol & $\begin{array}{l}\text { Demonstrated highest inhibitory activity against PL pro } \\
\qquad\left(\mathrm{IC}_{50}=3.7 \mu \mathrm{M}\right)\end{array}$ & [153] \\
\hline & Gallocatechin gallate & Inhibited wild-type SARS-CoV & [154] \\
\hline Euphoria nerifolia & 3ß-friedelanol & $\begin{array}{l}\text { Exhibited potent antiviral activity against SARS-CoV higher than } \\
\text { positive control }\end{array}$ & [149] \\
\hline \multirow[t]{4}{*}{ Istatis indigotica } & Hesperetin & Inhibited $3 C^{\text {pro }}$ effect via cell free and cell-based cleavage assays & [151] \\
\hline & Sinigrin & Inhibited $3 C L^{\text {pro }}$ effect via cell free and cell-based cleavage assays & [151] \\
\hline & Indigo & Inhibited $3 C^{\text {pro }}$ effect via cell free and cell-based cleavage assays & [151] \\
\hline & Emodin & Inhibited $3 C L^{\text {pro }}$ effect via cell free and cell-based cleavage assays & {$[142,155]$} \\
\hline
\end{tabular}

Abbreviations: $3 \mathrm{CL}^{\text {pro }}$, 3C-like protease; PL pro , papain-like protease; $\mathrm{IC}_{50}, 50 \%$ of inhibitory concentration.

As previously mentioned, none of the mentioned studies was conducted in in vivo models. The potential of the anti-coronavirus activity of the extracts can be evaluated in many existing animal models like non-human primates, hamsters, mice, and ferrets [144], which are developed to ideally reflect the pathology and clinical signs of SARS-CoV in humans. Recently, a mouse model expressing human angiotensin-converting enzyme 2 (hACE-2) [165] and SARS-CoV-2-infected Syrian hamster model [171] were established to study the infection biology of SARS-CoV-2. Future studies can therefore employ these animal models to evaluate the efficacy of medicinal plants or pure compounds against SARS-CoV-2 for the development of antiviral or therapeutics.

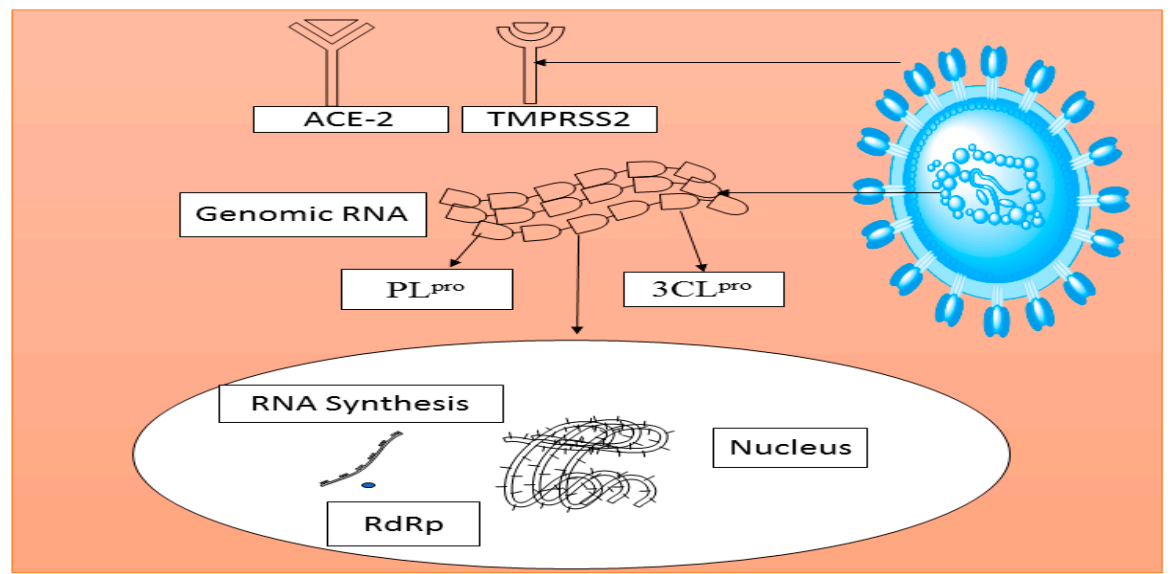

Figure 3. Schematic diagram of possible inhibitory sites against SARS-CoV that could be modulated by medicinal plants. ACE-2, angiotensin-converting enzyme 2; 3CL pro, 3C-like protease; PL pro, papain-like protease; RdRp, RNA-dependent RNA polymerase: TMPRSS2, transmembrane serine protease 2 .

\section{Conclusions and Future Prospects}

This review summarizes and updates various medicinal plants that are traditionally used to treat dengue and SARS-CoV-related infections, together with their pharmacological investigations against these viruses, using crude extracts or isolated/identified bioactive compounds. Many medicinal plants and pure compounds have shown promising activities even at clinical trials. However, many of the plants that are used traditionally for the infections are yet to be explored on their antiviral potentials. Extensive study is therefore 
needed to evaluate the potentials of these plants and their phytochemicals from in vitro to in vivo testing and then clinical studies.

Speedy identification of effective therapeutic measures against dengue and SARS-CoV has become a major challenge globally. Considering the fact that the development of new vaccines and synthetic drugs is highly time-consuming, it is therefore imperative to repurpose the alternative treatment or medications to suit the present situation. Alternative therapy from natural products seems to be capable of providing a valuable source for the swift discovery of antiviral drugs. The major challenge in the development of antiviral drugs that target specific viral proteins is the ability of the viruses to undergo rapid mutation during replication. Therefore, several aspects must be considered when evaluating the anti-dengue and anti-SARS-CoV-2 properties of medicinal herbs and pure compounds in terms of preparations, solvents, and techniques used for extraction. Many potent medicinal herbs reported here used polar solvents, which have been reported to aid in the attainment of the highest level of antiviral activity.

Even though a great number of research studies on anti-DENV and anti-SARS-CoV are still at initial stages, additional research is still very much required on the identification of the bioactive components, elucidation of the mechanisms of actions, evaluation of efficacy, and possible in vivo applications to promote the exploration of potent antiviral chemotherapeutics against these infections. Not much research has been done to study any potential immunomodulatory effects of the extracts or compounds, or their effects on signaling mechanisms leading to viral eradication. Additional investigations are also needed on the possibility of combining the existing treatment with natural bioactive compounds as a multiple-target solution to reduce the potentials of infection from drugresistant virus strains. Moreover, there is a need for the standardization of herbal medicines to enhance high reliability, effectiveness, quality, and safety, which will require a series of scientific experiments ranging from the isolation of the active major compounds to different biological testing; pharmacokinetics, toxicological, and clinical studies. It is hoped that natural remedies such as medicinal plants and pure bioactive metabolites will play a significant role in the development and advancement of anti-dengue and anti-coronavirus drugs that are safe, efficacious, and cost-effective. The effects of the medicinal plant crude extracts and bioactive compounds on DENV infection are summarized in Figures 4 and 5, while the effects of bioactive compounds on SARS-CoV infection is depicted in Figure 6. 


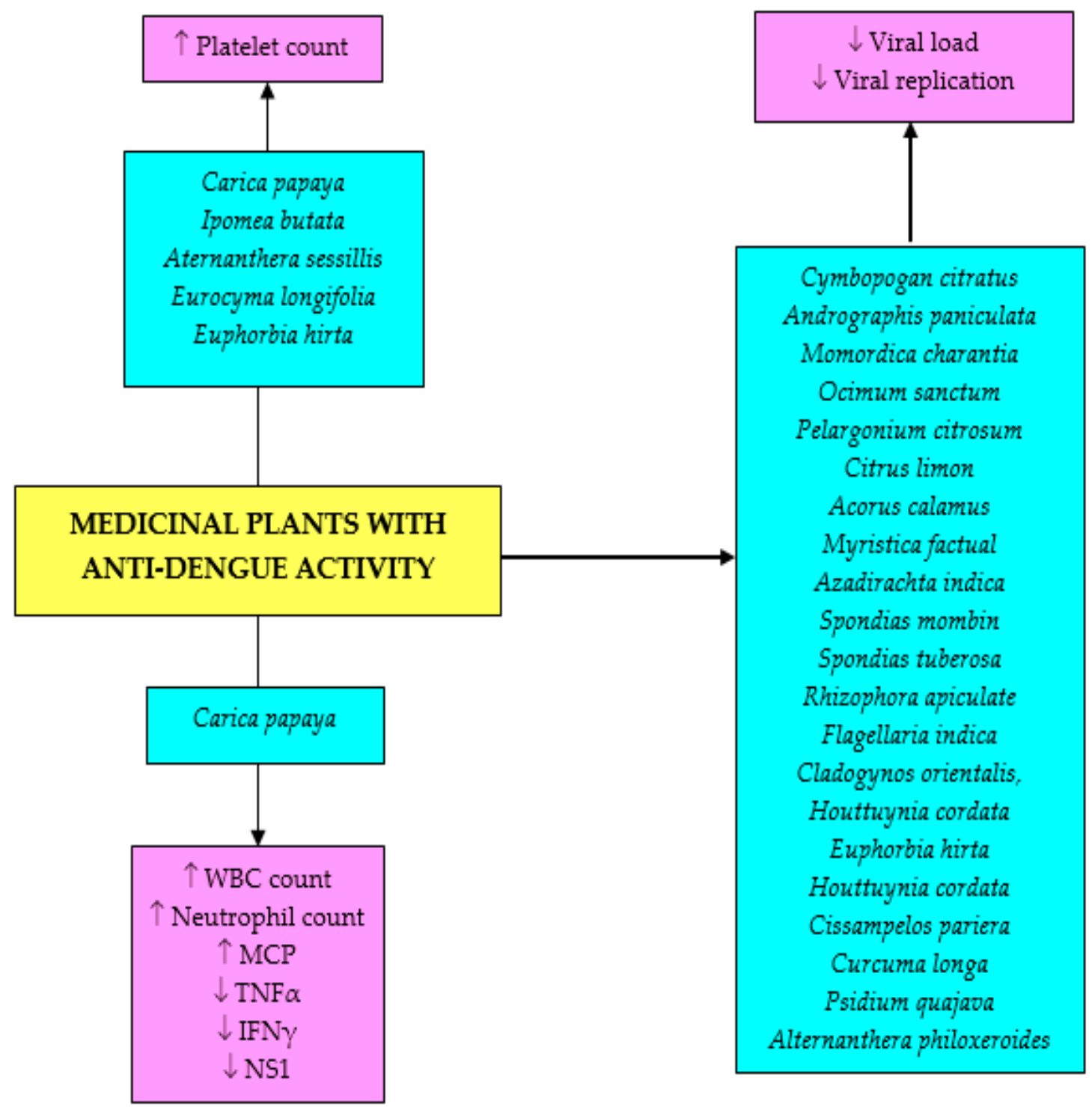

Figure 4. The effects of crude plant extracts on DENV infection. WBC, white blood cells; MCP, plasma monocyte chemoattractant protein; NS1, nonstructural protein $1 ; \mathrm{TNF} \alpha$, tumor necrosis factor- $\alpha$. 


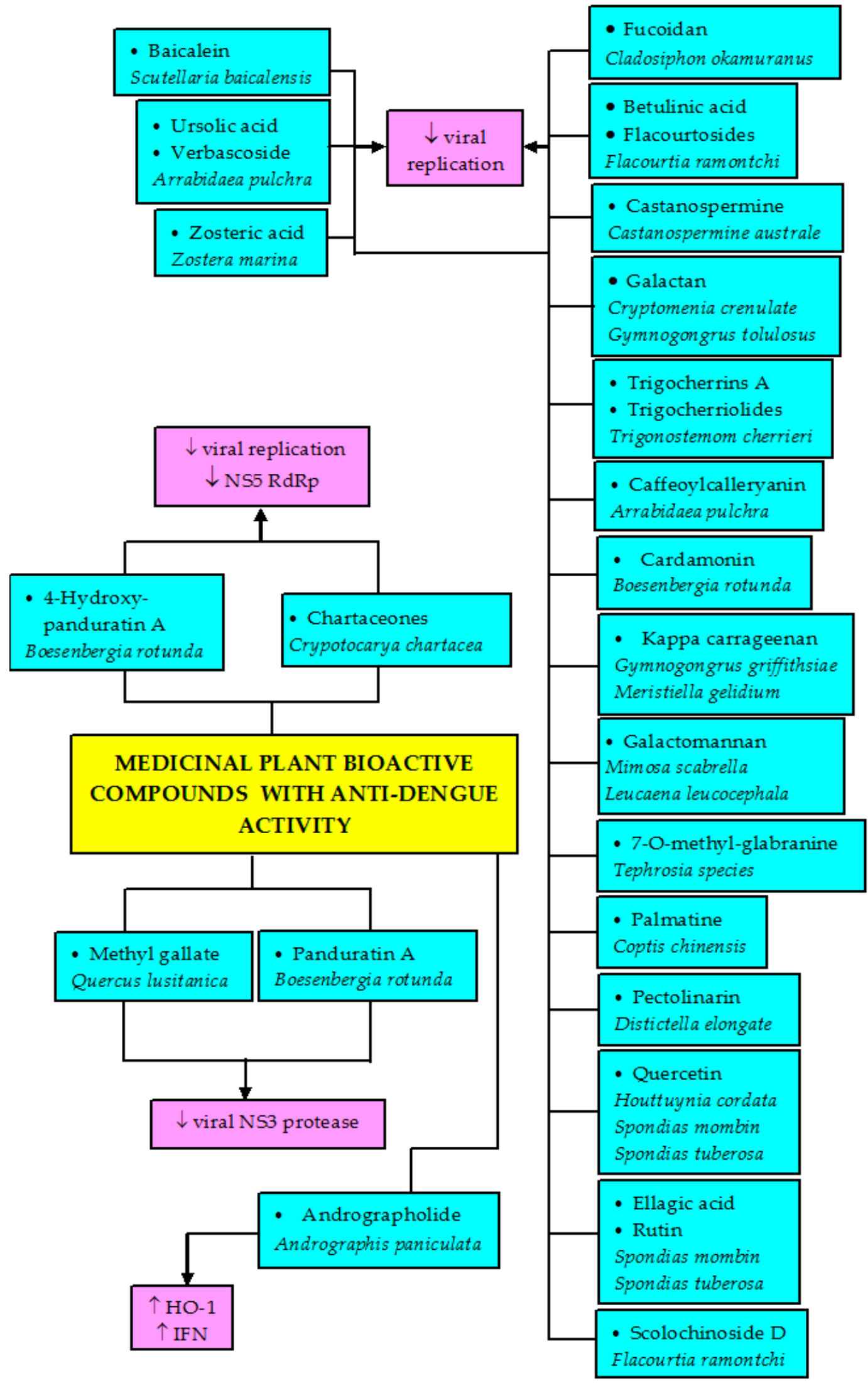

Figure 5. The effects of bioactive compounds isolated from plants with activity DENV infection. HO-1, heme oxygenase-1; IFN, interferon; NS5 RdRp, non-structural protein 5 RNA-dependent RNA polymerase; NS3, non-structural protein 3. 


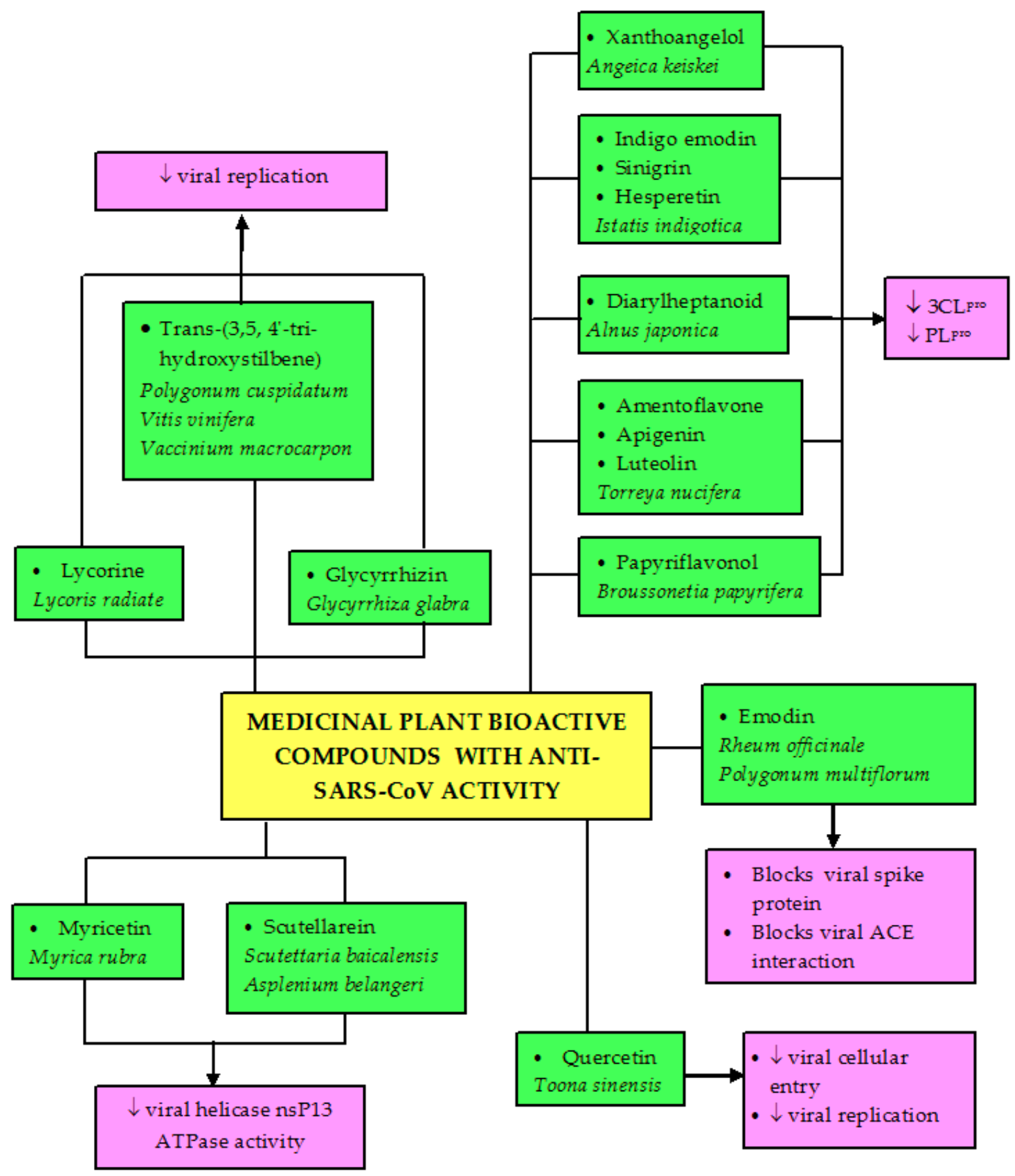

Figure 6. The effects of bioactive compounds isolated from plants with activity against SARS-CoV infection. ACE, angiotensin-converting enzyme; ATPase, adenosine triphosphatase; 3CL ${ }^{\text {ro }}, 3 C$-like protease; PL ${ }^{\text {pro }}$, papain-like protease.

Funding: This research was funded by the Ministry of Education Malaysia (grant number FRGS-12019-SKK10-UKM-02-1) and the APC was funded by the Faculty of Medicine, Universiti Kebangsaan, Malaysia.

Conflicts of Interest: The authors declare no conflict of interest. 


\section{References}

1. WHO Coronavirus Disease (COVID-19). Available online: https://www.who.int/emergencies/diseases/novel-coronavirus-2019 ?gclid=CjwKCAjwmf_4BRABEiwAGhDfSfUBiTxQG8b9kYVrWHD9pinxFCOxMnyC7tjIW6bkaoJq9HtVzyyNShoCDbIQAvD_ BwE (accessed on 28 July 2020).

2. WHO The Top 10 Causes of Death. Available online: https://www.who.int/news-room/fact-sheets/detail/the-top-10-causesof-death (accessed on 15 September 2020).

3. WHO Ebola Virus Disease. Available online: https://www.who.int/news-room/fact-sheets / detail/ebola-virus-disease (accessed on 14 August 2020).

4. Mansori, K.; Ayubi, E.; Shadmani, F.K.; Hanis, S.M.; Khazaei, S.; Sani, M.; Moradi, Y.; Khazaei, S.; Mohammadbeigi, A. Estimates of global HIV / AIDS mortality, prevalence and incidence rates, and their association with the Human Development Index. Biomed. Res. Ther. 2017, 4, 1399. [CrossRef]

5. Gasparini, R.; Amicizia, D.; Lai, P.L.; Panatto, D. Clinical and socioeconomic impact of seasonal and pandemic influenza in adults and the elderly. Hum. Vaccines Immunother. 2012, 8, 21-28. [CrossRef] [PubMed]

6. Nováková, L.; Pavlík, J.; Chrenková, L.; Martinec, O.; Červený, L. Current antiviral drugs and their analysis in biological materials-Part II: Antivirals against hepatitis and HIV viruses. J. Pharm. Biomed. Anal. 2018, 147, 378-399. [CrossRef] [PubMed]

7. Bhatt, S.; Gething, P.W.; Brady, O.J.; Messina, J.P.; Farlow, A.W.; Moyes, C.L.; Drake, J.M.; Brownstein, J.S.; Hoen, A.G.; Sankoh, O.; et al. The global distribution and burden of dengue. Nature 2013, 496, 504-507. [CrossRef]

8. Jiang, X.; Kanda, T.; Nakamoto, S.; Saito, K.; Nakamura, M.; Wu, S.; Haga, Y.; Sasaki, R.; Sakamoto, N.; Shirasawa, H.; et al. The JAK2 inhibitor AZD1480 inhibits hepatitis A virus replication in Huh7 cells. Biochem. Biophys. Res. Commun. 2015, 458, 908-912. [CrossRef]

9. Chung, T.H.; Kim, J.C.; Kim, M.K.; Choi, S.C.; Kim, S.L.; Chung, J.M.; Lee, I.S.; Kim, S.H.; Hahn, K.S.; Lee, I.P. Investigation of Korean plant extracts for potential phytotherapeutic agents against B-virus hepatitis. Phytother. Res. 1995, 9, 429-434. [CrossRef]

10. Akram, M.; Tahir, I.M.; Shah, S.M.A.; Mahmood, Z.; Altaf, A.; Ahmad, K.; Munir, N.; Daniyal, M.; Nasir, S.; Mehboob, H. Antiviral potential of medicinal plants against HIV, HSV, influenza, hepatitis, and coxsackievirus: A systematic review. Phytother. Res. 2018, 32, 811-822. [CrossRef]

11. Wang, J.; Peng, Y.; Xu, H.; Cui, Z.; Williams, R.O. The COVID-19 Vaccine Race: Challenges and Opportunities in Vaccine Formulation. AAPS PharmSciTech 2020, 21, 225. [CrossRef]

12. Thuener, J. Hepatitis A and B infections. Prim. Care Clin. Off. Pract. 2017, 44, 621-629. [CrossRef]

13. Ma, S.-J.; Li, X.; Xiong, Y.-Q. Combination measles-mumps-rubella-varicella vaccine in healthy children: A systematic review and meta-analysis of immunogenicity and safety. Medicine 2015, 94, e1721. [CrossRef]

14. Singh, R.; Singh, K.P.; Cherian, S.; Saminathan, M.; Kapoor, S.; Reddy, G.B.M.; Panda, S.; Dhama, K. Rabies-Epidemiology, pathogenesis, public health concerns and advances in diagnosis and control: A comprehensive review. Vet. Q. 2017, 37, 212-251. [CrossRef] [PubMed]

15. Perera, S.D.; Jayawardena, U.A.; Jayasinghe, C.D. Potential use of Euphorbia hirta for dengue: A systematic review of scientific evidence. J. Trop. Med. 2018, 2018. [CrossRef] [PubMed]

16. WHO WHO Epidemiology. Available online: https://www.who.int/denguecontrol/epidemiology/en/ (accessed on 8 August 2020).

17. Raja, D.B.; Mallol, R.; Ting, C.Y.; Kamaludin, F.; Ahmad, R.; Ismail, S.; Jayaraj, V.J.; Sundram, B.M. Artificial intelligence model as predictor for dengue outbreaks. Malays. J. Public Health Med. 2019, 19, 103-108. [CrossRef]

18. Grzybowski, A.; Tiboni, M.; da Silva, M.A.N.; Chitolina, R.F.; Passos, M.; Fontana, J.D. The combined action of phytolarvicides for the control of dengue fever vector, Aedes aegypti. Braz. J. Pharmacogn. 2012, 22, 549-557. [CrossRef]

19. Stanaway, J.D.; Shepard, D.S.; Undurraga, E.A.; Halasa, Y.A.; Coffeng, L.E.; Brady, O.J.; Hay, S.I.; Bedi, N.; Bensenor, I.M.; Castañeda-Orjuela, C.A.; et al. The global burden of dengue: An analysis from the global burden of disease study 2013 . Lancet Infect. Dis. 2016, 16, 712-723. [CrossRef]

20. Simo, F.B.N.; Bigna, J.J.; Kenmoe, S.; Ndangang, M.S.; Temfack, E.; Moundipa, P.F.; Demanou, M. Dengue virus infection in people residing in Africa: A systematic review and meta-analysis of prevalence studies. Sci. Rep. 2019, 9, 1-9. [CrossRef]

21. Goel, A.; Patel, D.N.; Lakhani, K.K.; Agarwal, S.B.; Agarwal, A.; Singla, S.; Agarwal, R. Dengue fever-a dangerous foe. J. Indian Acad. Clin. Med. 2004, 5, 247-258.

22. WHO Dengue and Severe Dengue. Available online: www.who.int/mediacentre/factsheets/fs117/en/index.html/ (accessed on 23 June 2020).

23. Gubler, D.J. Dengue/dengue haemorrhagic fever: History and current status. In Proceedings of the Novartis Foundation Symposium; Wiley Online Library: Chichester, UK, 2006; Volume 277, p. 3.

24. Guha-Sapir, D.; Schimmer, B. Dengue fever: New paradigms for a changing epidemiology. Emerg. Themes Epidemiol. 2005, 2, 1-10. [CrossRef]

25. Abd Kadir, S.L.; Yaakob, H.; Mohamed Zulkifli, R. Potential anti-dengue medicinal plants: A review. J. Nat. Med. 2013, 67, 677-689. [CrossRef]

26. Agnandji, S.T. Malaria vaccine: WHO position paper. N. Engl. J. Med. 2011, 356, $1863-1875$.

27. Fatima, K.; Syed, N.I. Dengvaxia controversy: Impact on vaccine hesitancy. J. Glob. Health 2018, 8, 8-11. [CrossRef] [PubMed]

28. CDC Centers for Disease Control and Prevention. Available online: https:/ / www.cdc.gov/ (accessed on 4 August 2020). 
29. Wang, C.; Horby, P.W.; Hayden, F.G.; Gao, G.F. A novel coronavirus outbreak of global health concern. Lancet 2020, 395, 470-473. [CrossRef]

30. Singhal, T. A Review of Coronavirus Disease-2019 (COVID-19). Indian J. Pediatr. 2020, 87, 281-286. [CrossRef] [PubMed]

31. Chan-yeung, M.; Xu, R. SARS: Epidemiology. Respirology 2003, 8, S9-S14. [CrossRef] [PubMed]

32. WHO Coronavirus Disease (COVID-19) Dashboard I WHO Coronavirus Disease (COVID-19) Dashboard. Available online: https: / / covid19.who.int/ (accessed on 4 August 2020).

33. Huang, C.; Wang, Y.; Li, X.; Ren, L.; Zhao, J.; Hu, Y.; Zhang, L.; Fan, G.; Xu, J.; Gu, X.; et al. Clinical features of patients infected with 2019 novel coronavirus in Wuhan, China. Lancet 2020, 395, 497-506. [CrossRef]

34. Wikipedia Template: Covid-19 Pandemic Data-Wikipedia. Available online: https://en.m.wikipedia.org/wiki/Template: Covid-19_pandemic_data (accessed on 17 August 2020).

35. Ridwan, R. COVID-19 and dengue: A deadly duo. Trop. Dr. 2020, 50, 270-272. [CrossRef]

36. Leardkamolkarn, V.; Sirigulpanit, W.; Phurimsak, C.; Kumkate, S.; Himakoun, L.; Sripanidkulchai, B. The inhibitory actions of Houttuynia cordata aqueous extract on dengue virus and dengue-infected cells. J. Food Biochem. 2012, 36, 86-92. [CrossRef]

37. Kiat, T.S.; Pippen, R.; Yusof, R.; Ibrahim, H.; Khalid, N.; Rahman, N.A. Inhibitory activity of cyclohexenyl chalcone derivatives and flavonoids of fingerroot, Boesenbergia rotunda (L.), towards dengue-2 virus NS3 protease. Bioorg. Med. Chem. Lett. 2006, 16, 3337-3340. [CrossRef]

38. Kanjanasirirat, P.; Suksatu, A.; Manopwisedjaroen, S.; Munyoo, B.; Tuchinda, P.; Jearawuttanakul, K.; Seemakhan, S.; Charoensutthivarakul, S.; Wongtrakoongate, P.; Rangkasenee, N.; et al. High-content screening of Thai medicinal plants reveals Boesenbergia rotunda extract and its component Panduratin A as Anti-SARS-CoV-2 agents. Res. Squre. 2020, 10, 19963. [CrossRef]

39. Lau, K.M.; Lee, K.M.; Koon, C.M.; Cheung, C.S.F.; Lau, C.P.; Ho, H.M.; Lee, M.Y.H.; Au, S.W.N.; Cheng, C.H.K.; Lau, C.B.S.; et al. Immunomodulatory and anti-SARS activities of Houttuynia cordata. J. Ethnopharmacol. 2008, 118, 79-85. [CrossRef]

40. Derosa, G.; Maffioli, P.; D'Angelo, A.; Di Pierro, F. A role for quercetin in coronavirus disease 2019 (COVID-19). Phytother. Res. 2020, 1-7. [CrossRef] [PubMed]

41. WHO Traditional, Complementary and Integrative Medicine. Available online: https://www.who.int/health-topics/traditionalcomplementary-and-integrative-medicine\#tab=tab_1 (accessed on 8 August 2020).

42. Saleh, M.S.M.; Siddiqui, M.J.; Mat So'ad, S.Z.; Roheem, F.O.; Saidi-Besbes, S.; Khatib, A. Correlation of FT-IR fingerprint and $\alpha$-glucosidase inhibitory activity of salak (Salacca zalacca) fruit extracts utilizing orthogonal partial least square. Molecules 2018, 23, 1434. [CrossRef] [PubMed]

43. Meneses, R.; Ocazionez, R.E.; Martínez, J.R.; Stashenko, E.E. Inhibitory effect of essential oils obtained from plants grown in Colombia on yellow fever virus replication in vitro. Ann. Clin. Microbiol. Antimicrob. 2009, 8, 8. [CrossRef] [PubMed]

44. Rates, S.M.K. Plants as source of new drugs. Toxicon 2001, 39, 603-613. [CrossRef]

45. Ganjhu, R.K.; Mudgal, P.P.; Maity, H.; Dowarha, D.; Devadiga, S.; Nag, S.; Arunkumar, G. Herbal plants and plant preparations as remedial approach for viral diseases. Virus Dis. 2015, 26, 225-236. [CrossRef]

46. Betancur-galvis, L.A.; Morales, G.E.; Forero, J.E.; Roldan, J. Cytotoxic and antiviral activities of Colombian medicinal plant extracts of the Euphorbia genus. Mem. Inst. Oswaldo Cruz. 2002, 97, 541-546. [CrossRef]

47. Ma, S.C.; Du, J.; But, P.P.H.; Deng, X.L.; Zhang, Y.W.; Ooi, V.E.C.; Xu, H.X.; Lee, S.H.S.; Lee, S.F. Antiviral Chinese medicinal herbs against respiratory syncytial virus. J. Ethnopharmacol. 2002, 79, 205-211. [CrossRef]

48. Rothan, H.; Zulqarnain, M.; Ammar, Y..; Tan, E..; Rahman, N..; Yusof, R. Screening of antiviral activities in medicinal plants extracts against dengue virus using dengue NS2B-NS3 protease assay. Trop. Biomed. 2014, 31, 286-296.

49. Lee, S.H.; Tang, Y.Q.; Rathkrishnan, A.; Wang, S.M.; Ong, K.C.; Manikam, R.; Payne, B.J.; Jaganath, I.B.; Sekaran, S.D. Effects of cocktail of four local Malaysian medicinal plants (Phyllanthus spp.) against dengue virus 2. BMC Complement. Altern. Med. 2013, 13, 192. [CrossRef]

50. Tang, L.I.C.; Ling, A.P.K.; Voon, K.G.L. Screening of anti-dengue activity in methanolic extracts of medicinal plants. BMC Complement. Altern. Med. 2014, 12, 3. [CrossRef]

51. Zhang, D.H.; Wu, K.L.; Zhang, X.; Deng, S.Q.; Peng, B. In silico screening of Chinese herbal medicines with the potential to directly inhibit 2019 novel coronavirus. J. Integr. Med. 2020, 18, 152-158. [CrossRef] [PubMed]

52. Das, S.; Sarmah, S.; Lyndem, S.; Singha Roy, A. An investigation into the identification of potential inhibitors of SARS-CoV-2 main protease using molecular docking study. J. Biomol. Struct. Dyn. 2020, 1-11. [CrossRef] [PubMed]

53. Macchiagodena, M.; Pagliai, M.; Procacci, P. Identification of potential binders of the main protease 3CLpro of the COVID-19 via structure-based ligand design and molecular modeling. Chem. Phys. Lett. 2020, 750, 137489. [CrossRef] [PubMed]

54. Aanouz, I.; Belhassan, A.; El-Khatabi, K.; Lakhlifi, T.; El-ldrissi, M.; Bouachrine, M. Moroccan Medicinal plants as inhibitors against SARS-CoV-2 main protease: Computational investigations. J. Biomol. Struct. Dyn. 2020, 1-9. [CrossRef]

55. Fiscal, R.R. Ethnomedicinal plants used by traditional healers in Laguna, Philippines. Asia Pac. J. Multidiscip. Res. 2017, 5, 132-137.

56. Philippine Medicinal Plants Philippine Medicinal Plants. Available online: http://www.stuartxchange.org/Papaya.html (accessed on 14 August 2020).

57. Chand, R.R.; Devi, S.S.; Kumari, S.S.; Kumar, S.S.; Goundar, N.N.; Naranyan, N.; Chandra, P. Traditional use of medicinal plants among selected villages in Fiji Islands: A review. Pac. Med. Stud. J. 2018, 1, 10-20. 
58. Sivasankari, B.; Pitchaimani, S.; Anandharaj, M. A study on traditional medicinal plants of Uthapuram, Madurai District, Tamilnadu, South India. Asian Pac. J. Trop. Biomed. 2013, 3, 975-979. [CrossRef]

59. Hossain, M.; Sharif, R.; Mamun, A.H.; Rayhana, N.; Begum, K.; Tripty, F.; Keya, A.S.; Shetu, S.; Ema, S.P.; Al-Nahain, A. Phytomedicines of traditional health-care professionals in the vicinity of Lawachara Forest Reserve, Moulvibazar district, Bangladesh. Am. Eurasian J. Sustain. Agric. 2014, 8, 51-60.

60. Gascon, M.G. Traditional ecological knowledge system of the matigsalug tribe in mitigating the effects of dengue and Malaria outbreak. Asian J. Health 2011, 1, 160-171. [CrossRef]

61. De Guzman, G.Q.; Dacanay, A.T.L.; Andaya, B.A.; Alejandro, G.J.D. Ethnopharmacological studies on the uses of Euphorbia hirta in the treatment of dengue in selected indigenous communities in pangasinan (Philippines). J. Intercult. Ethnopharmacol. 2016, 5, 239-243. [CrossRef]

62. Rahmatullah, M.; Mollik, M.A.H.; Azam, A.; Islam, M.R.; Chowdhury, M.A.M.; Jahan, R.; Chowdhury, M.H.; Rahman, T. Ethnobotanical survey of the santal tribe residing in Thakurgaon District, Bangladesh. Am. Eurasian J. Sustain. Agric. 2009, 3 , 889-898.

63. Hajdu, Z.; Hohmann, J. An ethnopharmacological survey of the traditional medicine utilized in the community of Porvenir, Bajo Paraguá Indian Reservation, Bolivia. J. Ethnopharmacol. 2012, 139, 838-857. [CrossRef] [PubMed]

64. Smita, S. Indigenous medicinal plants used for treatment of dengue fever by Tribals of Chhattisgarh (India). Int. J. Pharm. Bio. Sci. 2015, 6, 404-410.

65. Kandowangko, N.Y.; Latief, M.; Yusuf, R. Short communication: Inventory of traditional medicinal plants and their uses from Atinggola, North Gorontalo District, Gorontalo Province, Indonesia. Biodivers 2018, 19, 2294-2301. [CrossRef]

66. Rahmatullah, M.; Jahan, R.; Safiul Azam, F.M.; Hossan, S.; Mollik, M.A.H.; Rahman, T. Folk medicinal uses of verbenaceae family plants in Bangladesh. Afr. J. Tradit. Complement. Altern. Med. 2011, 8, 53-65. [CrossRef] [PubMed]

67. Singh, Y.N. Traditional medicine in Fiji: Some herbal folk cures used by Fiji Indians. J. Ethnopharmacol. 1986, 15, 57-88. [CrossRef]

68. Islam, M.K.; Saha, S.; Mahmud, I.; Mohamad, K.; Awang, K.; Jamal Uddin, S.; Rahman, M.M.; Shilpi, J.A. An ethnobotanical study of medicinal plants used by tribal and native people of Madhupur forest area, Bangladesh. J. Ethnopharmacol. 2014, 151, 921-930. [CrossRef]

69. Qasim, M.; Abideen, Z.; Adnan, M.Y.; Ansari, R.; Gul, B.; Khan, M.A. Traditional ethno-botanical uses of medicinal plants from coastal areas of Pakistan. J. Coast. Life Med. 2014, 2, 22-30. [CrossRef]

70. Gruya, G.A.; Roasario, R.D.; Palmes, N.D. Ethnomedicinal plants used by residents in Northern Surigao del Sur, Philippines. Nat. Prod. Chem. Res. 2014, 2, 2-6. [CrossRef]

71. Miano, R.S.; Picardal, J.P.; Alonso, C.A.G.; Reuyan, D. Ethnobotanical Inventory and assessment of medically-important plant roots in Cebu island, Philippines. Asian J. Biodivers 2011, 2, 81-102. [CrossRef]

72. Bradacs, G.; Heilmann, J.; Weckerle, C.S. Medicinal plant use in Vanuatu: A comparative ethnobotanical study of three islands. J. Ethnopharmacol. 2011, 137, 434-448. [CrossRef]

73. Bussmann, R.W.; Sharon, D. Traditional medicinal plant use in Northern Peru: Tracking two thousand years of healing culture. J. Ethnobiol. Ethnomed. 2006, 2, 60-70. [CrossRef]

74. Deep, P.; Srivastava, V.; Verma, S. Current perspectives of medicinal plants having anti dengue potential. Int. J. Pharm. Sci. Rev. Res. 2018, 49, 91-96.

75. Batoro, J.; Siswanto, D. Ethnomedicinal survey of plants used by local society in Poncokusumo district, Malang, East Java Province, Indonesia. Asian J. Med. Biol. Res. 2017, 3, 158-167. [CrossRef]

76. Patil, S.; Shetty, S.; Bhide, R.; Narayanan, S. Evaluation of platelet augmentation activity of Carica papaya leaf aqueous extract in rats. J. Pharm. Phytochem. 2013, 1, 57.

77. Arollado, E.C.; Pena, I.G.; Dahilig, V.R. Platelet augmentation activity of selected Philippine plants. Int. J. Pharm. Phytopharmacol. Res. 2014, 3, 121-123.

78. Coloma, A.J.L.; Casilla, A.S.B.; Estolero, B.; Ulalan, M.G.E.; Veloso, G.D.; MAN, R. Thrombocytotic efficacy of Tawa-Tawa, papaya and Malunggay among aspirin-induced laboratory rabbits. ICHAMS Health Care J. 2015, 5, 8-16.

79. George, A.; Zandi, K.; Biggins, J.; Chinnappan, S.; Hassandarvish, P.; Yusof, A. Antiviral activity of a standardized root water extract of Eurycoma longifolia (Physta ${ }^{\circledR}$ ) against dengue virus. Trop. Biomed. 2019, 36, 412-421.

80. Ichsyani, M.; Ridhanya, A.; Risanti, M.; Desti, H.; Ceria, R.; Putri, D.H.; Sudiro, T.M.; Dewi, B.E. Antiviral effects of Curcuma longa L. against dengue virus in vitro and in vivo. Conf. Ser. Earth Environ. Sci. 2017, 101, 012005. [CrossRef]

81. Parida, M.M.; Upadhyay, C.; Pandya, G.; Jana, A.M. Inhibitory potential of neem (Azadirachta indica Juss) leaves on Dengue virus type-2 replication. J. Ethnopharmacol. 2002, 79, 273-278. [CrossRef]

82. Norahmad, N.A.; Mohd Abd Razak, M.R.; Mohmad Misnan, N.; Md Jelas, N.H.; Sastu, U.R.; Muhammad, A.; Ho, T.C.D.; Jusoh, B.; Zolkifli, N.A.; Thayan, R.; et al. Effect of freeze-dried Carica papaya leaf juice on inflammatory cytokines production during dengue virus infection in AG129 mice. BMC Complement. Altern. Med. 2019, 19, 44. [CrossRef] [PubMed]

83. Krishnakumar, V.; Durairajan, S.S.K.; Alagarasu, K.; Li, M.; Dash, A.P. Recent updates on mouse models for human immunodeficiency, influenza, and dengue viral infections. Viruses 2019, 11, 252. [CrossRef] [PubMed]

84. Brandão, G.C.; Kroon, E.G.; Souza, D.E.R.; Filho, J.D.S.; Oliveira, A.B. Chemistry and antiviral activity of Arrabidaea pulchra (Bignoniaceae). Molecules 2013, 18, 9919-9932. [CrossRef] [PubMed] 
85. Silva, A.R.A.; Morais, S.M.; Marques, M.M.M.; Lima, D.M.; Santos, S.C.C.; Almeida, R.R.; Vieira, I.G.P.; Guedes, M.I.F. Antiviral activities of extracts and phenolic components of two Spondias species against dengue virus. J. Venom. Anim. Toxins Incl. Trop. Dis. 2011, 17, 406-413. [CrossRef]

86. Rosmalena, R.; Elya, B.; Dewi, B.E.; Fithriyah, F.; Desti, H.; Angelina, M.; Hanafi, M.; Lotulung, P.D.; Prasasty, V.D.; Seto, D. The antiviral effect of indonesian medicinal plant extracts against dengue virus in vitro and in silico. Pathogens 2019, 8, 85. [CrossRef]

87. Klawikkan, N.; Nukoolkarn, V.; Jirakanjanakit, N.; Yoksan, S.; Wiwat, C.; Thirapanmethee, K. Effect of Thai medicinal plant extracts against dengue virus in vitro. Mahidol. Univ. J. Pharm. Sci. 2011, 38, 13-18.

88. Ramalingam, S.; Karupannan, S.; Padmanaban, P.; Vijayan, S.; Sheriff, K.; Palani, G.; Krishnasam, K.K. Anti-dengue activity of Andrographis paniculata extracts and quantification of dengue viral inhibition by SYBR green reverse transcription polymerase chain reaction Senthilraja. Ayu 2018, 39, 87-91. [CrossRef]

89. Jiang, W.L.; Luo, X.L.; Kuang, S.J. Effects of Alternanthera philoxeroides Griseb against dengue virus in vitro. Di 1 jun yi da xue xue bao= Acad. J. First Med. Coll. PLA 2005, 25, 454-456.

90. Tayone, W.C.; Tayone, J.C.; Hashimoto, M. Isolation and structure elucidation of potential Anti-Dengue metabolites from Tawa-Tawa (Euphorbia hirta Linn.). Walailak J. Sci. Technol. 2014, 11, 825-832. [CrossRef]

91. Ahmad, N.; Fazal, H.; Ayaz, M.; Abbasi, B.H.; Mohammad, I.; Fazal, L. Dengue fever treatment with Carica papaya leaves extracts. Asian Pac. J. Trop. Biomed. 2011, 1, 330-333. [CrossRef]

92. Hettige S Salutary effects of Carica papaya leaf extract in dengue fever patients-a pilot study. Sri Lankan Family Physician 2008, 29, 17-19.

93. Subenthiran, S.; Choon, T.C.; Cheong, K.C.; Thayan, R.; Teck, M.B.; Muniandy, P.K.; Afzan, A.; Abdullah, N.R.; Ismail, Z. Carica papaya leaves juice significantly accelerates the rate of increase in platelet count among patients with dengue fever and dengue haemorrhagic fever. Evid.-Based Complement. Altern. Med. 2013, 2013, 1-8. [CrossRef] [PubMed]

94. Gadhwal, A.K.; Ankit, B.S.; Chahar, C.; Tantia, P.; Sirohi, P.; Agrawal, R.P. Effect of Carica papaya leaf extract capsule on platelet count in patients of dengue fever with thrombocytopenia. J. Assoc. Physicians India. 2016, 64, 22-26. [PubMed]

95. Yunita, F.; Hanani, E.; Kristianto, J. The effect of Carica papaya L. leaves extract capsules on platelets count and hematocrit level in dengue fever patient. Int. J. Med. Arom. Plants 2012, 2, 2249-4340.

96. Sathyapalan, D.T.; Padmanabhan, A.; Moni, M.; P-Prabhu, B.; Prasanna, P.; Balachandran, S.; Trikkur, S.P.; Jose, S.; Edathadathil, F.; Anilkumar, J.O.; et al. Efficacy \& safety of Carica papaya leaf extract (CPLE) in severe thrombocytopenia $(\leq 30,000 / \mu l)$ in adult dengue-Results of a pilot study. PLoS ONE 2020, 15, e0228699. [CrossRef]

97. Mir, M.; Khurshid, R.; Aftab, R. Management of thrombocytopenia and flu-like symptoms in dengue patients with herbal water of Euphorbia hirta. J. Ayub Med. Coll. Abbottabad. 2012, 24, 6-9.

98. Ling, A.P.K.; Khoo, B.F.; Seah, C.H.; Foo, K.Y.; Cheah, R.K.; Chye, S.O.; Koh, R.Y. Inhibitory activities of methanol extracts of Andrographis paniculata and Ocimum sanctum against dengue-1virus. In Proceedings of the International Conference on Biological, Environment and Food Engineering (BEFE-2014), Bali, Indonesia, 4-5 August 2014. [CrossRef]

99. Sathasivam, K.; Ramanathan, S.; Mansor, S.M.; Haris, M.R.M.H.; Wernsdorfer, W.H. Thrombocyte counts in mice after the administration of papaya leaf suspension. Wien. Klin. Wochenschr. 2009, 121, 19-22. [CrossRef]

100. Sood, R.; Raut, R.; Tyagi, P.; Pareek, P.K.; Barman, T.K.; Singhal, S.; Shirumalla, R.K.; Kanoje, V.; Subbarayan, R.; Rajerethinam, R.; et al. Cissampelos pareira Linn: Natural source of potent antiviral activity against all four dengue virus serotypes. PLoS Negl. Trop. Dis. 2015, 9, e0004255. [CrossRef]

101. Simões, L.R.; Maciel, G.M.; Brandão, G.C.; Kroon, E.G.; Castilho, R.O.; Oliveira, A.B. Antiviral activity of Distictella elongata (Vahl) Urb. (Bignoniaceae), a potentially useful source of anti-dengue drugs from the state of Minas Gerais, Brazil. Lett. Appl. Microbiol. 2011, 53, 602-607. [CrossRef]

102. Saptawati, L.; Febrinasari, R.P.; Yudhani, R.D.; Yono, H.; Faza, A.G.; Luthfiani, S.; Ummiyati, H.S.; Sudiro, T.M.; Dewi, B.E. In vitro study of eight Indonesian plants extracts as anti Dengue virus. Health Sci. J. Indones. 2017, 8, 12-18. [CrossRef]

103. Bourjot, M.; Leyssen, P.; Eydoux, C.; Guillemot, J.C.; Canard, B.; Rasoanaivo, P.; Guéritte, F.; Litaudon, M. Flacourtosides A-F, phenolic glycosides isolated from Flacourtia ramontchi. J. Nat. Prod. 2012, 75, 752-758. [CrossRef] [PubMed]

104. Nascimento, A.C.; Valente, L.M.M.; Gomes, M.; Barboza, R.S.; Wolff, T.; Neris, R.L.S.; Figueiredo, C.M.; Assunção-Miranda, I. Antiviral activity of Faramea bahiensis leaves on dengue virus type-2 and characterization of a new antiviral flavanone glycoside. Phytochem. Lett. 2017, 19, 220-225. [CrossRef]

105. Barboza, R.S.; Valente, L.M.M.; Wolff, T.; Assunção-Miranda, I.; Neris, R.L.S.; Guimarães-Andrade, I.P.; Gomes, M. Antiviral activity of Faramea hyacinthina and Faramea truncata leaves on dengue virus type-2 and their major compounds. Chem. Biodivers 2018, 15, e1700393. [CrossRef] [PubMed]

106. Wolff, T.; Berrueta, L.A.; Valente, L.M.M.; Barboza, R.S.; Neris, R.L.S.; Guimarães-Andrade, I.P.; Assunção-Miranda, I.; Nascimento, A.C.; Gomes, M.; Gallo, B.; et al. Comprehensive characterisation of polyphenols in leaves and stems of three anti-dengue virus type-2 active Brazilian Faramea species (Rubiaceae) by HPLC-DAD-ESI-MS/MS. Phytochem. Anal. 2019, 30, 62-72. [CrossRef] [PubMed]

107. Jain, M.; Ganju, L.; Katiyal, A.; Padwad, Y.; Mishra, K.P.; Chanda, S.; Karan, D.; Yogendra, K.M.S.; Sawhney, R.C. Effect of Hippophae rhamnoides leaf extract against Dengue virus infection in human blood-derived macrophages. Phytomedicine 2008, 15, 793-799. [CrossRef] [PubMed] 
108. Chiow, K.H.; Phoon, M.C.; Putti, T.; Tan, B.K.H.; Chow, V.T. Evaluation of antiviral activities of Houttuynia cordata Thunb. extract, quercetin, quercetrin and cinanserin on murine coronavirus and dengue virus infection. Asian Pac. J. Trop. Med. 2016, 9, 1-7. [CrossRef] [PubMed]

109. Xie, M.L.; Phoon, M.C.; Dong, S.X.; Tan, B.K.H.; Chow, V.T. Houttuynia cordata extracts and constituents inhibit the infectivity of dengue virus type 2 in vitro. Int. J. Integr. Biol. 2013, 14, 78-85.

110. Wilson, D.K.; Shyamala, G.; Paulpandi, M.; Narayanasamy, A.; Siram, K.; Karuppaiah, A.; Sankar, V. Development and characterization of phytoniosome nano vesicle loaded with aqueous leaf extracts of Justicia adhatoda and Psidium guajoava against dengue virus (DEN-2). J. Clust. Sci. 2020, 6. [CrossRef]

111. Trujillo-Correa, A.I.; Quintero-Gil, D.C.; Diaz-Castillo, F.; Quiñones, W.; Robledo, S.M.; Martinez-Gutierrez, M. In vitro and in silico anti-dengue activity of compounds obtained from Psidium guajava through bioprospecting. BMC Complement. Altern. Med. 2019, 19, 298. [CrossRef]

112. Muliawan, S.Y.; Kit, L.S.; Devi, S.; Hashim, O.; Yusof, R. Inhibitory potential of Quercus lusitanica extract on dengue virus type 2 replication. Southeast Asian J. Trop. Med. Public Health 2006, 37, 132-135.

113. Reis, S.R.I.N.; Valente, L.M.M.; Sampaio, A.L.; Siani, A.C.; Gandini, M.; Azeredo, E.L.; D’Avila, L.A.; Mazzei, J.L.; Maria das Graças, M.H.; Kubelka, C.F. Immunomodulating and antiviral activities of Uncaria tomentosa on human monocytes infected with dengue Virus-2. Int. Immunopharmacol. 2008, 8, 468-476. [CrossRef] [PubMed]

114. Wahab, N.Z.A.; Ibrahim, N.; Kamarudin, M.K.A.; Lananan, F.; Juahir, H.; Ghazali, A.; Yusra, A.F.I. Cytotoxicity and antiviral activity of Annona muricata aqueous leaves extract against dengue virus type 2. J. Fundam. Appl. Sci. 2018, 10, 580-589.

115. Zarina, N.; Wahab, A.; Nor, N.; Ibrahim, N. Efficacy of Catharanthus roseus extract against dengue virus type 2 tnfection in vitro. Indian J. Public Health Res. Dev. 2020, 11, 1577-1580.

116. Abd Wahab, N.Z.; Badya, N.; Ibrahim, N.; Kamarudin, M.K.A.; Juahir, H.; Toriman, M.E. Antiviral activity of Cynometra cauliflora leaves methanolic extract towards dengue virus type 2. Int. J. Eng. Technol. (UAE) 2018, 7, 344-347. [CrossRef]

117. Wahab, N.Z.A.; Ibrahim, N.; Kamarudin, M.K.A.; Lananan, F.; Juahir, H.; Ghazali, A. In vitro antiviral activity of Orthosiphon stamineus extract against dengue virus type 2. J. Fundam. Appl. Sci. 2018, 10, 541-551.

118. Panraksa, P.; Ramphan, S.; Khongwichit, S.; Smith, D.R. Activity of andrographolide against dengue virus. Antivir. Res. 2017, 139, 69-78. [CrossRef]

119. Edwin, E.S.; Vasantha-Srinivasan, P.; Senthil-Nathan, S.; Thanigaivel, A.; Ponsankar, A.; Pradeepa, V.; Selin-Rani, S.; Kalaivani, K.; Hunter, W.B.; Abdel-Megeed, A.; et al. Anti-dengue efficacy of bioactive andrographolide from Andrographis paniculata (Lamiales: Acanthaceae) against the primary dengue vector Aedes aegypti (Diptera: Culicidae). Acta Trop. 2016, 163, 167-178. [CrossRef]

120. Whitby, K.; Pierson, T.C.; Geiss, B.; Lane, K.; Engle, M.; Zhou, Y.; Doms, R.W.; Diamond, M.S. Castanospermine, a potent inhibitor of dengue virus infection in vitro and in vivo. J. Virol. 2005, 79, 8698-8706. [CrossRef]

121. Hidari, K.I.P.J.; Takahashi, N.; Arihara, M.; Nagaoka, M.; Morita, K.; Suzuki, T. Structure and anti-dengue virus activity of sulfated polysaccharide from a marine alga. Biochem. Biophys. Res. Commun. 2008, 376, 91-95. [CrossRef]

122. Talarico, L.B.; Pujol, C.A.; Zibetti, R.G.M.; Faría, P.C.S.; Noseda, M.D.; Duarte, M.E.R.; Damonte, E.B. The antiviral activity of sulfated polysaccharides against dengue virus is dependent on virus serotype and host cell. Antivir. Res. 2005, 66, 103-110. [CrossRef]

123. Pujol, C.A.; Estevez, J.M.; Carlucci, M.J.; Ciancia, M.; Cerezo, A.S.; Damonte, E.B. Novel DL-galactan hybrids from the red seaweed Gymnogongrus torulosus are potent inhibitors of herpes simplex virus and dengue virus. Antivir. Chem. Chemother. 2002, 13, 83-89. [CrossRef] [PubMed]

124. Talarico, L.B.; Duarte, M.E.R.; Zibetti, R.G.M.; Noseda, M.D.; Damonte, E.B. An algal-derived DL-galactan hybrid is an efficient preventing agent for in vitro dengue virus infection. Planta Med. 2007, 73, 1464-1468. [CrossRef] [PubMed]

125. De Sf-Tischer, P.C.; Talarico, L.B.; Noseda, M.D.; Silvia, S.M.; Damonte, E.B.; Duarte, M.E.R. Chemical structure and antiviral activity of carrageenans from Meristiella gelidium against herpes simplex and dengue virus. Carbohydr. Polym. 2006, 63, 459-465. [CrossRef]

126. Jasamai, M.; Boon, Y.W.; Sakulpanich, A.; Jaleel, A. Current prevention and potential treatment options for dengue infection. J. Pharm. Pharm. Sci. 2019, 22, 440-456. [CrossRef] [PubMed]

127. Allard, P.M.; Dau, E.T.H.; Eydoux, C.; Guillemot, J.C.; Dumontet, V.; Poullain, C.; Canard, B.; Guéritte, F.; Litaudon, M. Alkylated flavanones from the bark of cryptocarya chartacea as dengue virus NS5 polymerase inhibitors. J. Nat. Prod. 2011, 74, $2446-2453$. [CrossRef] [PubMed]

128. Allard, P.M.; Leyssen, P.; Martin, M.T.; Bourjot, M.; Dumontet, V.; Eydoux, C.; Guillemot, J.C.; Canard, B.; Poullain, C.; Guéritte, F.; et al. Antiviral chlorinated daphnane diterpenoid orthoesters from the bark and wood of Trigonostemon cherrieri. Phytochemistry 2012, 84, 160-168. [CrossRef]

129. Sharma, V.; Sharma, A.; Bharate, S.B. Natural products in mitigation of SARS CoV Infections. Curr. Med. Chem. 2020. [CrossRef]

130. Tseng, C.K.; Lin, C.K.; Wu, Y.H.; Chen, Y.H.; Chen, W.C.; Young, K.C.; Lee, J.C. Human heme oxygenase 1 is a potential host cell factor against dengue virus replication. Sci. Rep. 2016, 6, 32176. [CrossRef]

131. Ono, L.; Wollinger, W.; Rocco, I.M.; Coimbra, T.L.M.; Gorin, P.A.J.; Sierakowski, M.R. In vitro and in vivo antiviral properties of sulfated galactomannans against yellow fever virus (BeH111 strain) and dengue 1 virus (Hawaii strain). Antivir. Res. 2003, 60, 201-208. [CrossRef] 
132. Sánchez, I.; Gómez-Garibay, F.; Taboada, J.; Ruiz, B.H. Antiviral effect of flavonoids on the dengue virus. Phytother. Res. 2000, 14, 89-92. [CrossRef]

133. Rahman, N.A.; Hadinur; Muliawan, S.; Rashid, N.N.; Muhamad, M.; Yusof, R. Studies on Quercus Iusitanica extracts on DENV-2 replication. Dengue Bull. 2006, 30, 260-269.

134. Jia, F.; Zou, G.; Fan, J.; Yuan, Z. Identification of palmatine as an inhibitor of West Nile virus. Arch. Virol. 2010, 155, 1325-1329. [CrossRef] [PubMed]

135. Zandi, K.; Teoh, B.T.; Sam, S.S.; Wong, P.F.; Mustafa, M.R.; AbuBakar, S. Novel antiviral activity of baicalein against dengue virus BMC Complement. Altern. Med. 2012, 12, 214. [CrossRef] [PubMed]

136. Rees, C.R.; Costin, J.M.; Fink, R.C.; McMichael, M.; Fontaine, K.A.; Isern, S.; Michael, S.F. In vitro inhibition of dengue virus entry by p-sulfoxy-cinnamic acid and structurally related combinatorial chemistries. Antivir. Res. 2008, 80, 135-142. [CrossRef] [PubMed]

137. Ferrari, M.; Zevini, A.; Palermo, E.; Muscolini, M.; Alexandridi, M.; Etna, M.P.; Coccia, E.M.; Fernandez-Sesma, A.; Coyne, C.; Zhang, D.D. Dengue virus targets Nrf2 for NS2B3-mediated degradation leading to enhanced oxidative stress and viral replication. J. Virol. 2020, 94, 1-20. [CrossRef]

138. Valadão, A.L.C.; Aguiar, R.S.; de Arruda, L.B. Interplay between inflammation and cellular stress triggered by Flaviviridae viruses. Front. Microbiol. 2016, 7, 1233. [CrossRef]

139. Siti, H.N.; Jalil, J.; Asmadi, A.Y.; Kamisah, Y. Roles of rutin in cardiac remodeling. J. Funct. Foods. 2020, 64, 103606. [CrossRef]

140. Gui, J.S.; Jalil, J.; Jubri, Z.; Kamisah, Y. Parkia speciosa empty pod extract exerts anti-inflammatory properties by modulating NFkB and MAPK pathways in cardiomyocytes exposed to tumor necrosis factor- $\alpha$. Cytotechnology 2019, 71, 79-89. [CrossRef]

141. Wu, T.; Peng, Y.; Yan, S.; Li, N.; Chen, Y.; Lan, T. Andrographolide ameliorates atherosclerosis by suppressing pro-inflammation and ROS generation-mediated foam cell formation. Inflammation 2018, 41, 1681-1689. [CrossRef]

142. Zhang, A.; Wan, B.; Jiang, D.; Wu, Y.; Ji, P.; Du, Y.; Zhang, G. The Cytoprotective Enzyme Heme Oxygenase-1 Suppresses Pseudorabies Virus Replication in vitro. Front. Microbiol. 2020, 11, 412. [CrossRef]

143. Kamisah, Y.; Lim, J.J.; Lim, C.L.; Asmadi, A.Y. Inhibitory effects of palm tocotrienol-rich fraction supplementation on bilirubinmetabolizing enzymes in hyperbilirubinemic adult rats. PLoS ONE 2014, 9, e0089248. [CrossRef] [PubMed]

144. Gretebeck, L.M.; Subbarao, K. Animal models for SARS and MERS coronaviruses. Curr. Opin. Virol. 2015, 13, 123-129. [CrossRef]

145. Wyganowska-Swiatkowska, M.; Nohawica, M.; Grocholewicz, K.; Nowak, G. Influence of herbal medicines on hmgb1 release, sars-cov-2 viral attachment, acute respiratory failure, and sepsis. A literature review. Int. J. Mol. Sci. 2020, 21, 1-26. [CrossRef]

146. Chen, Z.; Nakamura, T. Statistical evidence for the usefulness of Chinese medicine in the treatment of SARS. Phytother. Res. 2004, 18, 592-594. [CrossRef] [PubMed]

147. Shahrajabian, M.H.; Sun, W.; Shen, H.; Cheng, Q. Chinese herbal medicine for SARS and SARS-CoV-2 treatment and prevention, encouraging using herbal medicine for COVID-19 outbreak. Acta Agric. Scand. Sect. B Soil Plant Sci. 2020, 70, 437-443. [CrossRef]

148. Chen, C.J.; Michaelis, M.; Hsu, H.K.; Tsai, C.C.; Yang, K.D.; Wu, Y.C.; Cinatl, J.; Doerr, H.W. Toona sinensis Roem tender leaf extract inhibits SARS coronavirus replication. J. Ethnopharmacol. 2008, 120, 108-111. [CrossRef] [PubMed]

149. Chang, F.R.; Yen, C.T.; Ei-Shazly, M.; Lin, W.H.; Yen, M.H.; Lin, K.H.; Wu, Y.C. Anti-human coronavirus (anti-HCoV) triterpenoids from the leaves of Euphorbia neriifolia. Nat. Prod. Commun. 2012, 7, 1415-1417. [CrossRef]

150. Wen, C.C.; Shyur, L.F.; Jan, J.T.; Liang, P.H.; Kuo, C.J.; Arulselvan, P.; Wu, J.B.; Kuo, S.C.; Yang, N.S. Traditional chinese medicine herbal extracts of Cibotium barometz, Gentiana scabra, Dioscorea batatas, Cassia tora, and Taxillus chinensis inhibit sars-cov replication. J. Tradit. Complement. Med. 2011, 1, 41-50. [CrossRef]

151. Lin, C.W.; Tsai, F.J.; Tsai, C.H.; Lai, C.C.; Wan, L.; Ho, T.Y.; Hsieh, C.C.; Chao, P.D.L. Anti-SARS coronavirus 3C-like protease effects of Isatis indigotica root and plant-derived phenolic compounds. Antivir. Res. 2005, 68, 36-42. [CrossRef]

152. Park, J.Y.; Ko, J.A.; Kim, D.W.; Kim, Y.M.; Kwon, H.J.; Jeong, H.J.; Kim, C.Y.; Park, K.H.; Lee, W.S.; Ryu, Y.B. Chalcones isolated from Angelica keiskei inhibit cysteine proteases of SARS-CoV. J. Enzyme Inhib. Med. Chem. 2016, 31, 23-30. [CrossRef]

153. Park, J.Y.; Yuk, H.J.; Ryu, H.W.; Lim, S.H.; Kim, K.S.; Park, K.H.; Ryu, Y.B.; Lee, W.S. Evaluation of polyphenols from Broussonetia papyrifera as coronavirus protease inhibitors. J. Enzyme Inhib. Med. Chem. 2017, 32, 504-512. [CrossRef] [PubMed]

154. Zhuang, M.; Jiang, H.; Suzuki, Y.; Li, X.; Xiao, P.; Tanaka, T.; Ling, H.; Yang, B.; Saitoh, H.; Zhang, L.; et al. Procyanidins and butanol extract of Cinnamomi cortex inhibit SARS-CoV infection. Antivir. Res. 2009, 82, 73-81. [CrossRef] [PubMed]

155. Bhowmik, D.; Nandi, R.; Kumar, D. Evaluation of flavonoids as 2019-nCoV cell entry inhibitor through molecular docking and pharmacological analysis. ChemRxiv 2020, 6, 1-27. Available online: https://chemrxiv.org/articles/preprint/Evaluation_of_ Flavonoids_as_2019-nCoV_Cell_Entry_Inhibitor_Through_Molecular_Docking_and_Pharmacological_Analysis/12071508 (accessed on 15 December 2020).

156. Yi, L.; Li, Z.; Yuan, K.; Qu, X.; Chen, J.; Wang, G.; Zhang, H.; Luo, H.; Zhu, L.; Jiang, P.; et al. Small molecules blocking the entry of severe acute respiratory syndrome coronavirus into host cells. J. Virol. 2004, 78, 11334-11339. [CrossRef] [PubMed]

157. Yu, M.S.; Lee, J.; Lee, J.M.; Kim, Y.; Chin, Y.W.; Jee, J.G.; Keum, Y.S.; Jeong, Y.J. Identification of myricetin and scutellarein as novel chemical inhibitors of the SARS coronavirus helicase, nsP13. Bioorganic Med. Chem. Lett. 2012, 22, 4049-4054. [CrossRef] [PubMed]

158. Tanner, J.A.; Zheng, B.; Zhou, J.; Watt, R.M.; Jiang, J.; Wong, K.; Lin, Y.; Lu, L.; He, M.; Kung, H.; et al. The adamantane-derived bananins are potent inhibitors of the helicase activities and replication of SARS coronavirus. Chem. Biol. 2005, 12, 303-311. [CrossRef] [PubMed] 
159. Lin, S.C.; Ho, C.T.; Chuo, W.H.; Li, S.; Wang, T.T.; Lin, C.C. Effective inhibition of MERS-CoV infection by resveratrol. BMC Infect. Dis. 2017, 17, 144. [CrossRef]

160. Li, S.Y.; Chen, C.; Zhang, H.Q.; Guo, H.Y.; Wang, H.; Wang, L.; Zhang, X.; Hua, S.N.; Yu, J.; Xiao, P.G.; et al. Identification of natural compounds with antiviral activities against SARS-associated coronavirus. Antivir. Res. 2005, 67, 18-23. [CrossRef]

161. Cinatl, J.; Morgenstern, B.; Bauer, G.; Chandra, P.; Rabenau, H.; Doerr, H.W. Glycyrrhizin, an active component of Liquorice roots, and replication of SARS-associated coronavirus. Lancet 2003, 361, 2045-2046. [CrossRef]

162. Ho, T.Y.; Wu, S.L.; Chen, J.C.; Li, C.C.; Hsiang, C.Y. Emodin blocks the SARS coronavirus spike protein and angiotensin-converting enzyme 2 interaction. Antivir. Res. 2007, 74, 92-101. [CrossRef]

163. Schwarz, S.; Wang, K.; Yu, W.; Sun, B.; Schwarz, W. Emodin inhibits current through SARS-associated coronavirus 3a protein. Antivir. Res. 2011, 90, 64-69. [CrossRef] [PubMed]

164. Yin, J.; Niu, C.; Cherney, M.M.; Zhang, J.; Huitema, C.; Eltis, L.D.; Vederas, J.C.; James, M.N.G. A Mechanistic View of enzyme inhibition and peptide hydrolysis in the active site of the sars-cov 3c-like peptidase. J. Mol. Biol. 2007, 371, 1060-1074. [CrossRef] [PubMed]

165. Ryu, Y.B.; Jeong, H.J.; Kim, J.H.; Kim, Y.M.; Park, J.Y.; Kim, D.; Naguyen, T.T.H.; Park, S.J.; Chang, J.S.; Park, K.H.; et al.

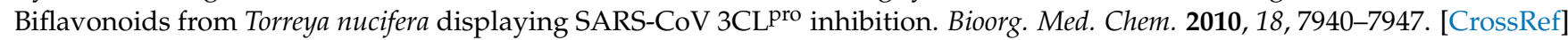
[PubMed]

166. Park, J.Y.; Jeong, H.J.; Kim, J.H.; Kim, Y.M.; Park, S.J.; Kim, D.; Park, K.H.; Lee, W.S.; Ryu, Y.B. Diarylheptanoids from Alnus japonica inhibit papain-Like protease of severe acute respiratory syndrome coronavirus. Biol. Pharm. Bull. 2012, b12-00623. [CrossRef] [PubMed]

167. Keyaerts, E.; Vijgen, L.; Pannecouque, C.; Van Damme, E.; Peumans, W.; Egberink, H.; Balzarini, J.; Van Ranst, M. Plant lectins are potent inhibitors of coronaviruses by interfering with two targets in the viral replication cycle. Antivir. Res. 2007, 75, 179-187. [CrossRef] [PubMed]

168. Hsieh, L.E.; Lin, C.N.; Su, B.L.; Jan, T.R.; Chen, C.M.; Wang, C.H.; Lin, D.S.; Lin, C.T.; Chueh, L.L. Synergistic antiviral effect of Galanthus nivalis agglutinin and nelfinavir against feline coronavirus. Antivir. Res. 2010, 88, 25-30. [CrossRef] [PubMed]

169. Heurich, A.; Hofmann-Winkler, H.; Gierer, S.; Liepold, T.; Jahn, O.; Pohlmann, S. TMPRSS2 and ADAM17 Cleave ACE2 Differentially and Only Proteolysis by TMPRSS2 Augments Entry Driven by the Severe Acute Respiratory Syndrome Coronavirus Spike Protein. J. Virol. 2014, 88, 1293-1307. [CrossRef]

170. Beltrán-García, J.; Osca-Verdegal, R.; Pallardó, F.V.; Ferreres, J.; Rodríguez, M.; Mulet, S.; Sanchis-Gomar, F.; Carbonell, N.; García-Giménez, J.L. Oxidative Stress and Inflammation in COVID-19-Associated Sepsis: The Potential Role of Anti-Oxidant Therapy in Avoiding Disease Progression. Antioxidants 2020, 9, 936. [CrossRef]

171. Imai, M.; Iwatsuki-Horimoto, K.; Hatta, M.; Loeber, S.; Halfmann, P.J.; Nakajima, N.; Watanabe, T.; Ujie, M.; Takahashi, K.; Ito, M.; et al. Syrian hamsters as a small animal model for SARS-CoV-2 infection and countermeasure development. Proc. Natl. Acad. Sci. USA 2020, 117, 16587-16595. [CrossRef] 